Article

\title{
Analysis of the Risk of Bankruptcy of Tomato Processing Companies Operating in the Inter-Regional Interprofessional Organization "OI Pomodoro da Industria Nord Italia"
}

\author{
Mattia Iotti ${ }^{1, *}$ (1) and Giuseppe Bonazzi ${ }^{2,3}$ \\ 1 Department of Civil Engineering, Environment, Territory and Architecture (DICATeA), University of Parma, \\ 43124 Parma, Italy \\ 2 Department of Veterinary Science, University of Parma, 43126 Parma, Italy; giuseppe.bonazzi@unipr.it \\ 3 University of Buenos Aires, Buenos Aires C1417DSE, Argentina \\ * Correspondence: mattia.iotti@unipr.it; Tel.: +39-521-03-2709
}

Received: 15 February 2018; Accepted: 22 March 2018; Published: 24 March 2018

check for updates

\begin{abstract}
The tomato sector is a major area of agricultural activity in Italy; tomato production and processing characterize different Italian regions; in particular, there are two production districts, one in southern Italy and one in northern Italy, in the Po Valley. In recent years, processing firms have encountered increasing difficulties, due both to an increase in raw material costs and market difficulties. Tomato processing firms are often characterized by significant investment in fixed assets and working capital, with an ensuing increase in equity or debt financing, which increases the risk of bankruptcy, as has happened to many firms in the sector in recent years. Therefore, the aim of this research was to analyze the financial sustainability of tomato processing firms by applying financial ratios. To achieve this goal, this research focused on the annual data of a sample of 17 tomato processing firms operating in the Inter-regional Interprofessional Organization, "OI Pomodoro da Industria Nord Italia". The firms were divided into still-active (not-distressed) and failed (distressed) firms, with the aim of analyzing the differences between the financial data and management practices of the two groups. The data suggest that larger firms, with an adequate financial structure, have been able to withstand the tomato market crisis in recent years, whereas distressed firms are on average smaller and suffer from higher recourse to debt capital and lower profit margins than not-distressed firms. This research could be applied by entrepreneurs, managers, bankers and public operators to define good management practices that should be achieved and measured with financial ratios, even as a means of reducing the risk of distress for firms operating in the tomato sector. This research highlights that financial ratios could be usefully applied for predicting the continuity of activity and therefore the sustainability of the management cycle, including its relationship to the whole socio-economic system over time.
\end{abstract}

Keywords: interprofessional organization; "OI Pomodoro da Industria Nord Italia"; tomato processing firms in Italy; bankruptcy; distressed firms; financial sustainability; management cycle

\section{Introduction}

Tomato production (from industry or table, grown in the field or in the greenhouse) and the tomato processing industry characterize the economy of territories in different areas of the world. Internationally, Italy, alongside the western United States of America, in particular the state of California, China and some Mediterranean countries, including Spain, Portugal and Turkey, is one of the major regions for the production and processing of tomatoes worldwide. At a national level, 
the production of tomatoes from industry, transformed into sauces, juices and similar products, especially characterizes two areas of Italy; the first is the southern regions of Italy (Campania, Puglia and Basilicata), while the second is in the northern regions, in the Po Valley (Emilia-Romagna, Lombardia and Piemonte, in particular). These two Italian districts have different production specializations: The North mainly produces concentrates $(39.3 \%)$, pulps $(35 \%)$, pastes $(27.3 \%)$ and ready sauces $(1.7 \%)$; the Center and South mainly produce peeled tomatoes $(44 \%)$, pulps and pastes $(48 \%)$, and concentrates $(8 \%)$. In the pulp and peeled segment, the world's leading exporter is Italy, with a share of over $75 \%$ of the world's value, followed by Spain $(6 \%)$ and the USA (4\%). Compared to 2012, Italian exports increased by $12 \%$ in 2016, as did those in the United States (11.3\%), while those in Spain suffered a setback $(-18.9 \%)$. In the same segment, the world's largest importer is the United Kingdom (23\%), followed by Germany (15\%) and France (9\%); compared to 2012, value imports rose in all countries in 2016, with the exception of Japan and Australia. Italy is also in first place for export of pastes and concentrated stocks, with a $26 \%$ share, slightly above China (25\%) with the US ranking third $(12 \%)$. In contrast, Italy is the second largest importer of tomato purees and concentrates (especially the latter), with a 10\% share and significant increases in money flow in 2016 compared to $2012(+54.4 \%)$, [1]. Italian production is mostly destined for foreign markets, which makes Italy the world's top exporter of processed tomatoes worldwide. In this context, important changes have occurred in recent years that have changed the geography of tomato production and processing worldwide. Several emerging countries, including China, have increased tomato production, with consequent changes also in the dynamics of international trade, both quantitatively and qualitatively. These observed changes must be considered by firms in the national sector in order to orient strategies for differentiating and enhancing production in the market, and to motivate research on the economic and financial efficiency of the firm to improve management in the sector. Also, the international level is characterized by the growing presence of large firms located in Asian and South American countries, which can produce with significant savings in production costs, both in the procurement of materials and the use of labor. There are various reasons for these trends, including the rising costs of raw material supplies and increased competition in the processed product, and at the macroeconomic level, the international economic crisis that has led to difficulties in finding bank credit.

Firms in this sector have production structures that require high investments in fixed capital, especially for tomato processing plants and for storage facilities for the finished product. These capital needs are then amplified during the summer, when there is a peak in production; in fact, in the summer, firms buy the product by financing working capital that is derived from the process of purchase, transformation and sale. The product is sold during the year, which determines the need for capital to finance the warehouse cycle and trade receivables. The cycle of working capital also causes a dilation of the investments of the firms in the sector; the sales of products to the major food retailers (Grande Distribuzione Organizzata, GDO, in Italian) leads to an extension in the collection times of the receivables with negative effects on the financial sustainability of the business cycle, particularly in the net working capital (NWC) cycle. Moreover, processing firms do not always produce their own brands, but often produce with a food distribution brand, which further reduces their commercial power in business-to-business negotiations and processing firms frequently suffer from low brand loyalty among consumers, thus reducing their bargaining power.

The Common Agricultural Policy (CAP) has also had on effect on the financial profitability of the tomato sector. For example, in harmony with the rest of EU policy, Regulation (EC) No. 1182/2007 concerning the reform of the fruit and vegetable sector, decoupled public aid. Article 5 of National Decree No. 1540/2007 defines the applied guidelines for the implementation of the CAP reform in the tomato sector, granting payment at the single farm level to support farm income [2-5].

The changes observed must also be considered by companies in the national sector in order to develop strategies for differentiating and enhancing production, with regard to the relationship with the market, and in terms of research of the economic and financial efficiency of the company; and for improved management in the sector. Also, at an international level, characterized by the growing 
presence of large companies, many of which are located in Asian and South American countries, companies must be able to produce significant savings in production costs, both in the procurement of materials and the use of labor. Regarding the industry, the continuity of tomato production can only be guaranteed through the canning industry's payment of a remunerative price to producers. Therefore, farmers will have to try to contain production costs while ensuring high levels of food quality and safety. To remain competitive, the industry will have to reduce unit costs through size economies, pursue strategies for integration with production, and implement production differentiation policies. The increase in organic tomato cultivation areas for industrial processing is a response to these efforts to differentiate production with higher added-value production. The alternative is the risk that production will be abandoned by farmers.

The objective of the analysis was to highlight the structural characteristics of the firms, both in terms of financial structure and return on capital, by dividing the firms into two sub-groups: the first being firms that are still active (not-distressed) and the second being firms following bankruptcy (distressed). In the research, a financial ratio analysis is applied to achieve two different goals: (1) define the financial performance and capital structure of the firms operating in the tomato processing sector; (2) quantify the differences between the distressed and not-distressed firms operating in the tomato processing sector (in terms of the differences of financial ratios). To achieve this goal the research considers the annual data of a sample of 17 tomato processing firms operating in the inter-regional interprofessional organization, "OI Pomodoro da Industria Nord Italia". The aim was to analyze the differences between the financial data and management practices of the two groups of firms (not-stressed and distressed). Following this, financial ratios were applied first, because they may be useful for the entrepreneur as a means of correctly assessing the sustainability of the financial cycle in advance; and, secondly, both for the lenders (who are thus able to evaluate more correctly the creditworthiness of the firms) and for the policy maker (who may intervene with direct or indirect (guarantee consortia) aid policies in favor of the firms for whom the use of public funds is deemed proper), thus reducing the risk of inefficient use of public funds. The analysis is also relevant for risk analysis in food supply chains and the relationships between public operators and private operators [6]. In fact, the tomato sector plays an important role in the food supply chain, as it involves production firms that deal with primary production, processing firms and small and large distribution firms. Alongside these main operators, the production and processing firms provide work, especially during the peak of summer production, to many personnel, hired directly or hired by work and porter cooperatives. In various Po Valley territories, seasonal work represents a significant income supplement in the production areas and the processing factories employ several thousand seasonal workers during the summer. The management of risk therefore has an effect not only on firms, but also on all those (including tomato producers, workers and even the State) for which the continuity of the firms' business and risk forecasting is essential. In this regard, the merger and aggregation processes of firms, especially when managed without bankruptcy cases, can improve the firms' efficiency. In fact, integration operations in the supply chain were favored by the State with the reform of the Civil Code implemented in Legislative Decrees No. 5 and 6 of 17 January 2003, which came into force on 1 January 2004. These decrees modified the Italian regulations governing joint-stock firms and cooperatives and simplified the business amalgamation process, including the regulation of mergers between firms.

This article first presents the methods shown in previous literature on the subject of business crises and the prediction of crisis states. Then, the article presents analyses of the firms' financial data and their usefulness in assessing financial sustainability and firm efficiency according to the objectives of the study. The results section provides the context of Italian tomato production, both in terms of production and in terms of transformation, in order to describe the territories of northern Italy under study. Next, is the analysis of the business data of the firms included in the sample which compares the data from the group of firms that have failed (distressed) to the non-bankrupt firms (not-distressed) in order to highlight significant differences between the financial ratios in the two groups of firms. In this way, this study aims to show the managers of tomato firms and policy makers the relevant 
financial parameters of the failed firms compared to still-active firms. These indicators can help to define good management practices, reveal the future development of the sector, guide managerial conduct and allow third parties (such as suppliers, banks and public operators) to predict crises in the sector. Finally, the main results, limitations and possible developments in the method and applications of the study are discussed. To date, there have been no studies investigating this issue. Nevertheless, the results of this study are based on a small sample of firms and therefore cannot create general crisis prediction indicators, but it can give results that are specific to the sector of tomato processing. Still, this work has novel features, despite its limited applicability to the sector under analysis.

\section{Methods}

\subsection{Annual Account Statement (AAS) Analysis}

The annual account statement (AAS) is the main document for the analysis of the economic, equity and financial situation of the firms. In Italy, this document is mandatory for firms that are active as a joint-stock firm or a cooperative. It is the main source of information required by law for the protection of third parties who have business relationships with firms. The AAS is the main record of external corporate information and consists of a balance sheet, income statement and explanatory notes. The AAS is governed by Articles 24 and 23 of the Civil Code; these articles of the law define, in a rigid way, the AAS structure and its informative content. The adoption of the AAS by firms makes it possible to have a homogeneous information base on a European and national basis, drawn up on the basis of uniform accounting standards, and this favors the comparison between the data of firms operating in different sectors or of different firms operating in the same sector. Again, AAS is the primary document, together with the Central Bank of Risks of the Bank of Italy, used by banks to assess the creditworthiness of firms; the valuation of the financial statements is also of interest in the assessment of the creditworthiness by banks. The evaluation of the operating performance is an issue that affects both the choices of the entrepreneur and the decisions of all those persons who have relationships with the company. AAS is drawn up by the board of directors of a company and submitted for approval to its shareholders, and with the input of the auditors and the board of statutory auditors, if appointed; the document is drafted and approved each year. Financial statements were amended into Italian legislation by the content of the Fourth Council Directive of 1978, which started the process of unification at the European level in terms of financial statements. The National legislature implemented EEC Directives IV and VII with Legislative Decree No. 127 on 9 April 1991, with which community provisions were transposed into national legislation via a radical alteration of the entire body of legislation relating to the financial statements of public firms, contained in the Civil Code. Today, the regulations of the financial statements are governed by Legislative Decree 139 of 18 August 2015, which implements the European Directive 2013/34/EU. The annual account statement (AAS) is mandatory, as it is the main document used to inform third parties of a firm's business performance, in terms of economic, equity and financial results. This is a document required by law, governed by European regulations and by the National Civil Code in Italy and, therefore, is the main database for the analysis of corporate data by all third parties who have relations with a firm. Therefore, AAS are also freely available for researchers. Furthermore, the AAS is a document that, by law, must be truthful, because in the case of bankruptcy there are significant penalties, including the crime of bankruptcy, for those who have falsified AAS data. Therefore, AAS data was used in this research because, being obligatory, it allows us to compare firms' data and represents a data base that is as real and correct as possible for the firms included in the sample. The annual account is composed of a balance sheet statement (BSS), an income statement (IS) and a cash flow statement (CFS).

Regarding the format of the balance sheet statement (BSS), the legislation imposes a pattern of contrasting sections divided into balance sheet assets, expressive of the investments, and balance sheet liabilities and equity, expressive of sources financing. The format of BSS applies homogeneous categories for investment and source of capital, divided into further subcategories. The balance sheet 
assets (expressed as a total asset, TA) assume a classification of numbers based on the destination of the investments, based on the type of use for which the investment is targeted in the management of the firm. The balance sheet liabilities are classified on the basis of the origins of the sources of financing, that is, the parties who have made funds available for the financing, divided first by the equity and debt sources of the capital (expressed as the total source of capital, TS). The legislation then suggests a partial reclassification of the receivables and payables and the underlying maturity, distinguishing between funds maturing before and after 12 months, (a limit which is conventionally referred to as a short period), thus determining the time of the realization of assets (loans) and the settlement of liabilities (debts or funding sources). We can represent the BSS equation as follows [7]:

$$
\begin{aligned}
& \mathrm{A}+\mathrm{Bfa}^{\mathrm{int}}+\mathrm{Bfa}^{\mathrm{tan}}+\mathrm{Bfa}^{\mathrm{fin}}+\mathrm{Cwc}^{\mathrm{ar}<12 \mathrm{~m}}+\mathrm{Cwc}^{\mathrm{ar}>12 \mathrm{~m}}+\mathrm{Cwc}^{\mathrm{o}<12 \mathrm{~m}}+\mathrm{Cwc}^{\mathrm{o}>12 \mathrm{~m}}+ \\
& +\mathrm{Cwc}^{\mathrm{i}}+\mathrm{Cwc}^{\mathrm{ql}}+\mathrm{CL}+\mathrm{D}^{+}=\mathrm{AE}^{\mathrm{sc}}+\mathrm{AE}^{\mathrm{r}}+\mathrm{AE}^{\Pi}+\mathrm{A} \Pi+\mathrm{B}+\mathrm{C}+\mathrm{Df}^{<12 \mathrm{~m}}+ \\
& +\mathrm{Df}^{>12 \mathrm{~m}}+\mathrm{Dwc}^{\mathrm{ap}<12 \mathrm{~m}}+\mathrm{Dwc}^{\mathrm{ap}>12 \mathrm{~m}}+\mathrm{Dwc}^{\mathrm{o}<12 \mathrm{~m}}+\mathrm{Dwc}^{\mathrm{o}>12 \mathrm{~m}}+\mathrm{D}^{-}
\end{aligned}
$$

In Equation (1), the left side expresses the balance sheet assets (TA); the right side expresses the total liabilities and the total sources of capital (TS). On the left side of Equation (1), A represents the receivables from shareholders for capital subscription, $\mathrm{Bfa}^{\mathrm{int}}$ represents intangible fixed assets, $\mathrm{Bfa}^{\mathrm{tan}}$ represents tangible fixed assets, $\mathrm{Bfa}^{\text {fin }}$ represents financial fixed assets, and $\mathrm{Bfa}^{\mathrm{int}}+\mathrm{Bfa}^{\mathrm{tan}}+\mathrm{Bfa}^{\mathrm{fin}}=\mathrm{BFA}$; BFA represents the total amount of capital invested in fixed assets. $\mathrm{CWc}^{\mathrm{ar}<12 \mathrm{~m}}$ represents the working capital accounts receivable in the short period (due within 12 months), $\mathrm{Cwc}^{\mathrm{ar}>12 \mathrm{~m}}$ represents the working capital accounts receivable after the short period (due after 12 months), $C w c^{\circ<12 m}$ represents the working capital other credits in the short period (due within 12 months), $\mathrm{CWc}^{\mathrm{O}>12 \mathrm{~m}}$ represents the working capital other credits after the short period (due after 12 months), $C w c^{i}$ represents the working capital inventories, $\mathrm{CWC}^{\mathrm{ql}}$ represents the working capital investment comparable to cash, $\mathrm{CL}$ represents the working capital liquidity, and $\mathrm{D}^{+}$represents the positive active accrued accruals and deferrals. In Equation (1), on the right side, $\mathrm{AE}^{\mathrm{sc}}$ represents the share capital, $\mathrm{AE}^{\mathrm{r}}$ represents the reserves, $\mathrm{AE}^{\Pi}$ represents the retained profit from previous years, $\mathrm{A} \Pi$ represents the net profit from the year, and $\mathrm{AE}^{\mathrm{sC}}+\mathrm{AE}^{\mathrm{r}}+\mathrm{AE}^{\Pi}+\mathrm{A} \Pi=\mathrm{E}$, where $\mathrm{E}$ represents the total shareholder capital, defined jointly as equity (E). B represents the provisions for risks and charges, and $C$ represents the termination indemnities paid to workers. $\mathrm{Df}^{<12 \mathrm{~m}}$ represents the financial debts expiring in the short period (due within 12 months), $\mathrm{Df}^{>12 \mathrm{~m}}$ represents the financial expiring after the short period (due after 12 months), $\mathrm{Dwc}^{\mathrm{ap}<12 \mathrm{~m}}$ represents the accounts payable of working capital expiring in the short period (due within 12 months), Dwc $c^{\text {ap }}>12 \mathrm{~m}$ represents the accounts payable of working capital expiring after the short period (due after 12 months), $\mathrm{Dw}^{\mathrm{co}<12 \mathrm{~m}}$ represents the other working capital debts expiring in the short period (due within 12 months), $\mathrm{Dw}^{\mathrm{co}<12 \mathrm{~m}}$ represents the other working capital debts expiring after the short period (due after 12 months), and $\mathrm{D}^{-}$represents the negative active accrued accruals and deferrals. In Equation (1), B $+C+\mathrm{Df}^{<12 \mathrm{~m}}+\mathrm{Df}^{<12 \mathrm{~m}}+\mathrm{Dw} \mathrm{c}^{\mathrm{ap}<12 \mathrm{~m}}+\mathrm{Dw} \mathrm{c}^{\mathrm{ap}>12 \mathrm{~m}}+\mathrm{Dw} \mathrm{c}^{\mathrm{o}<12 \mathrm{~m}}+\mathrm{Dw} \mathrm{c}^{\mathrm{0}>12 \mathrm{~m}}$ $+\mathrm{D}^{-}=\mathrm{D}^{\mathrm{T}}$, where $\mathrm{D}^{\mathrm{T}}$ is the total debt, expressed as the total amount of capital given by third parties in terms of debt financing. The net amount of cash due to banks and other financial intermediaries is called the net financial position (NFP) and is expressed as follows: NFP $=\mathrm{Df}^{<12 \mathrm{~m}}+\mathrm{Df}^{>12 \mathrm{~m}}-\mathrm{CL}$; NFP assumes a fundamental role in quantifying: (a) the cost of debt in terms of debt financing; (b) the (net) total amount of financial debt to be repaid to financial institutions. Equation (1) is applied to quantify a fundamental margin available to pay debts due within 12 months using active elements from the balance sheet, that is, the net working capital (NWC), calculated as the difference between the current assets $\left(\mathrm{WCi}^{\mathrm{T}}\right)$ and liabilities $\left(\mathrm{WCs}^{\mathrm{T}}\right)$, as follows: $\mathrm{NWC}=\mathrm{WCi}^{\mathrm{T}}-\mathrm{WCs}^{\mathrm{T}}$ where $\mathrm{WCi}^{\mathrm{T}}=$

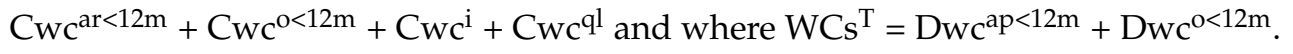

In AAS, the Italian legislature require the drafting and publication of income statements (IS); IS quantify a firm's profit through the exposure of intermediate profit margins and by isolating different areas of value creation and absorption. IS are exposed according to the principle of value creation, 
which considers the positive elements of income regardless of the moment of financial change, i.e., collection or payment. In our research, IS has been used with Equation (2), as follows [7]:

$$
\begin{aligned}
& \left(\mathrm{S} \pm \Delta \mathrm{Cwc} \mathrm{c}^{\mathrm{i}}+\mathrm{Cp}+\mathrm{Os}\right)-(\mathrm{Mc}+\mathrm{Sc}+\mathrm{Rc}+\mathrm{Lc}+\mathrm{Oc})=\mathrm{VP}-\mathrm{MC}=\mathrm{EBITDA} \\
& \mathrm{EBITDA}-(\mathrm{Dc}+\mathrm{Ac})=\mathrm{EBIT} ; \mathrm{EBIT}+(\mathrm{Ir}-\mathrm{Ic})+(\mathrm{Rc}-\mathrm{Dc})+(\mathrm{Xr}-\mathrm{Xc})= \\
& =\mathrm{EBIT}+\mathrm{SF}+\mathrm{SR}+\mathrm{SX}=\Pi^{\mathrm{bT}} \\
& \Pi^{\mathrm{bT}}-\mathrm{T}=\Pi
\end{aligned}
$$

In Equation (2), $\mathrm{S}$ is the total amount of sales (net of discount), $\Delta \mathrm{Cwc} \mathrm{c}^{\mathrm{i}}$ is the change in inventory value, to be considered as a positive or negative source of income according to the value creation principle, $\mathrm{Cp}$ is the total amount of capitalized costs, and Os is other positive sources of income. The sum of $S, \Delta C w c^{i}, C p$ and Os represents the total value of production (VP), that is, the total amount of value generated by current operations. Considering the costs, Mc represents the total amount spent for raw materials acquisition, $\mathrm{Sc}$ is the costs of services, Rc is the total amount of renting and leasing and Oc is the total amount of other costs. The sum of Mc, Sc, Rc, Lc and Oc represents the total amount of monetary cost of production (MC), that is, the total amount of monetary cost acquired to generate current operation value. The difference between VP and EC is earnings before interest, tax, depreciations and amortizations (EBITDA), which expresses income margins available to approximate liquidity generations through current operations. Dc and Ac are depreciations and amortizations. The difference between EBITDA and Dc + Ac is earnings before interest and tax (EBIT); EBIT is a fundamental income margin that expresses the value generated by current operations that is available to cover financial costs and remunerate share capital; EBIT is the major income margins applied to quantify a firm's capacity to create value through transformation, which is particularly relevant in the valuation of processing firms' management efficiency. After EBIT, IS considers the financial revenues and costs, where Ir is interest revenue and Ic is interest charge; Ir - Ic = SF, where SF is the result of financial revenues and costs. After SF, $R r$ is revaluation and $\mathrm{Dc}$ is devaluation; $\mathrm{Rr}-\mathrm{Dc}=\mathrm{SR}$, where $S R$ is the result of the impairments of financial assets; $X_{r}$ is extraordinary revenue, while $X_{c}$ is extraordinary cost; $\mathrm{Xr}-\mathrm{X}_{\mathrm{C}}=\mathrm{SX}$, where $\mathrm{SX}$ is the balance of extraordinary operations. $\Pi^{\mathrm{bT}}$ is profit before taxes, while $\mathrm{T}$ is income taxes. $\Pi$ is net profit. $\mathrm{A} \Pi$ in the balance sheet is equal to the $\Pi$ of the income statement. The income statement (IS) does not take into account the cash conversion cycle, and income margins (EBITDA, EBIT and $\Pi$ ) do not directly express cash flow generation; this lack of information for income margins has been shown by several studies about capital intensive firms regarding fixed assets $[8,9]$ and working capital $[10,11]$ investment.

We can consider, in a given time $t$, that if $\Pi>$ FCFE $>0$ (where FCFE is Free Cash Flow to Equity, as the cash flow is available to equity holders), it is then possible to pay to equity holders the dividend in a share $\alpha$ of the profit equal to $1>\alpha>0$ without increasing financial debt $\left(\Delta^{+} \mathrm{FP}_{t}\right)$ as $\alpha \Pi=\mathrm{FCFE}_{\mathrm{t}}=\mathrm{d}_{\mathrm{t}}$. Alternatively, the payment to equity holders could be given for a share $\beta$, where $1 \geq \beta>\alpha>0$, with an increase in $\mathrm{NFP}_{\mathrm{t}}$ so that $\beta \Pi=\mathrm{FCFE}_{\mathrm{t}}+\Delta^{+} \mathrm{NFP}_{\mathrm{t}}=\mathrm{d}_{\mathrm{t}}$, or $\beta \Pi=\mathrm{FCFE}_{\mathrm{t}}+\Delta^{+} \mathrm{NFP}_{\mathrm{t}+1}=\mathrm{d}_{\mathrm{t}}$, if the distribution of the dividend takes place at the time $t+1$.

The data of Equations (1) and (2), as described, are derived from the accounting of firms, which is required by law. The firms' accounting data are processed by the directors and presenters in the AAS, which is filed with the Business Register every year. Therefore, for tomato processing firms, AAS data represent the main database for carrying out analysis and research. All values of AAS are expressed in currency (euro); these values do not consider inflation and are not discounted. Therefore, the analysis of AAS provides significant information in the short term, preferably in the absence of inflation or high availability of interest rates. 
The applied approach has some limitations that must be considered. First, the AAS data have limitations, as the data are influenced by the accounting rules for determining income (including the rule of prudence for the protection of third parties) and the exposure of firm assets (always according to the rule of prudence). In addition, financial ratios compare flow values (including income flows) with stock values (including asset values); the comparison of flow and stock values is therefore not homogeneous, which can distort the results, especially for firms characterized by seasonality of production (therefore without constant stock values during the fiscal year). Second, as a specific limitation of the study, the sample of firms was relatively small (17 firms); therefore, generalization of the results obtained is not possible, given the low sample size. Moreover, 12 corporations and 5 cooperative firms were considered in the sample and the comparison between these two different types of enterprises (the first with gainful activity, the second with mutualistic activity) might be a further limitation for the applicability of the results to other sectors.

\subsection{Financial Ratio Analysis}

Derived from AAS data, the financial ratio (FR) analysis is based on the accrual basis, thereby taking into account the time value creation derived from the facts of management. Ratios and margins are identified and used in the analysis as they can provide information on financial performance (profitability), as well as patrimonial and financial aspects of firm management.

The use of financial ratios has, first of all, the purpose of evaluating the efficiency of firm management $[12,13]$. This application of financial ratios had its first application in the financial offices of the DuPont chemical firm, who used an integrated system of ratios, later known as the DuPont Chart, to assess managers' performance and assess the level of risk capital return [14]. The application of the balance sheet indexes has been developed in several ways, including the application of the Economic Value Added $\left(\mathrm{EVA}^{\circledR}\right)$ method to the measurement of managerial performance (Stern) and in terms of other performance indicators [15,16], including Shareholder Value Added (SVA), Market Value Added (MVA), Cash Flow Return on Investment (CFROI) and Cash Value Added (CVA). Another widely-known application of financial ratios is the forecasting of firm crises. The first studies were carried out in the thirties [17] and focused on the search for relationships between the different aspects of business management and the state of insolvency. The application of financial ratios to credit scoring has the purpose of estimating in advance the risk associated with granting a loan, the probability that a debtor becomes insolvent, mainly through the use of quantitative data. The decision-making process is based on a cut-off score, which is in fact the limit point at which the firm moves from a healthy firm to an insolvent firm. A fundamental study on financial ratios was conducted in the sixties on a sample of 158 firms, of which 79 were distressed and 79 not-distressed [18], using univariate analysis. Compared to the previous approaches, univariate analysis has greater rigor, but is limited by the impossibility of considering interdependences between the different reference indexes. To overcome this limit, subsequent studies have applied multivariate discriminant analysis (MDA); this technique overcomes the limits of univariate analysis by applying multidimensional statistical methodologies to the analysis of balance sheets by indices. A model constructed in this way is predictive, as it is able to anticipate the future states of insolvency of firms similar to those examined. In fact, by comparing the indices calculated for the firms to be entrusted (or monitored) and those obtained from past experience, the model allows estimating with a reasonable degree of approximation if a specific production unit (provided of certain characteristics) will be able to meet its commitments or become insolvent. The first and most fundamental application of MDA was from Altman [19], with a sample of 66 firms (33 distressed and 33 not-distressed), which gave rise to the well-known Z-Score, which the same author then developed into the EM-Score [20], which is aimed at classifying firms in a given rating class, i.e., default risk. The application of MDA has also been relevant in the agricultural sector, with analyses aimed at paying bank debts [21] and envisaging a progressive increase in explanatory variables [22]. MDA is able to provide a dichotomous indication, dividing firms between distressed and not-distressed, but is limited by not providing indications in terms of 
probability of insolvency. This can be provided by the linear probability models, Logit and Probit [23], that have been variously applied in the prediction of insolvency, including in the field of agricultural firms [24-28]. National responsibilities include controlling accounting fraud and taking measures to protect firms whose accounting data show early warning signals of crisis [29] to prevent these signals from become self-fulfilling prophecies of failure. In this sense, the public guarantee consortia, the bankruptcy instruments of the current bankruptcy law reform and the dissemination of a managerial and entrepreneurial culture of preventing crises can play important roles in the formation of social sustainability and the continuity of business activity, with its multiple socio-economic relationships which, in the event of failure, are inevitably dispersed, together with intellectual capital. It is important to consider that, in addition to the firm's accounting data, other data are also necessary to build and validate a predictive model of insolvency, such as macroeconomic and sector performance data and the behavioral characteristics of management. Again, external elements, such as wars, political upheavals and technical and scientific progress make insolvency unpredictable, at least in the long run. Finally, perfect predictability of firms' bankruptcy through a model (and the disclosure of the results of this model) would result in a zero-risk reduction and, therefore, would reduce the rate of return of invested capital at the risk rate free level, thus reducing the attractiveness of this sector for investors. Only if the model were not made public, could $f$ information asymmetry be maintained in favor of subjects who, knowing the model, could predict in advance (to the detriment of those unfamiliar with the model) the insolvency of some firms, and thus drive investments towards those firms destined to remain active; this would have evident disadvantages for parts of the community.

The most recent insolvency predictive techniques have recourse to improvements in data processing techniques made possible by the development of computing power; a wide range of methods can be traced back to recent artificial intelligence techniques like the neural network (NN) approach. In this field, the Back Propagation Neural Network (BPNN) has been applied [30]. Recently, several promising techniques have been developed [31,32], all characterized by no need for assumptions of probability distribution, like the genetic algorithm (GA), rough set theory (RST) and support vector machine (SVM). The aim of all these techniques is to improve the prediction of insolvency by considering subjective elements, erratic behavior and the action of human beings, which are difficult to model in traditional approaches to the prediction of insolvency [33-37].

In this field of research, a firm's continuity also has social value. In fact, a firm is part of a network of relations in a given territory (such as labor relations, supply and sales relationships, financial reports, tax payment reports, social relations, etc.). Identifying managerial behaviors that preserve the continuity of the firm (as, in the case of this research, through financial ratios that highlight how a firm's conduct is predictive of crisis) allows an analysis to evolve from a mere sustainability assessment to a social sustainability assessment of the firm. A firm's continuity is important to ensure the viability of the socio-economic system and, therefore, sustainability over time [38-42]. Focusing attention on the prediction of insolvency does not limit the expulsion of inefficient firms from the sector. Rather, consider that the uncontrolled loss of firms (uncontrolled means damaging to third parties in terms of unemployment, loss of capital and loss of continuity of business relationships) must be assessed as a harm to the community; therefore, third parties associated with firms rationally destined to failure (in the absence of the corrective behaviors of managers) can act promptly to reduce the risk derived from relations with firms characterized by financial ratios expressive of insolvency. This theme illustrates the problem of a self-fulfilling prophecy, as firms characterized by "negative" financial ratios are "abandoned" by third parties at the first sign of risk; this eventuality involves the risk of manipulating accounting data in order not to reveal weaknesses the first signs of crises outside the firms to induce trust in commercial relations with third parties.

The ratio analysis is made primarily with an analysis of IS and BSS data. The approach is developed through the identification of synthetic indicators of efficiency; calculations are made in terms of profitability, solidity of the balance sheet and liquidity. This methodology allows for its values to be rendered absolute and also allows a comparison between firms of different sizes and 
different sectors; the budget analysis has a greater credibility when it is not analyzed in a single year, but rather covers a number of years. In this way it is possible to identify anomalous trends of business management, though this is limited to a single year; in this case the data emerges as an anomalous value of the time series of indexes, such as the presence of components of extraordinary income that affect the overall profitability. It is also possible that the data is caused by extraordinary transactions, reflected in the management as abnormal results in determining ratios. It is also necessary to consider that the financial ratios, as based on accounting data, are formed by the aggregation and comparison of the carrying amounts, and that they are influenced by accounting standards for the preparation of the AAS. Financial ratios are then applicable, when the limits inherent in the accrual basis of the preparation of the IS and BSS are considered; these two tables are in fact the database logic of ratio calculation. The IS has been prepared as a flow document that expresses and summarizes the total number of positive and negative income components that are counted over a year. The BSS is drawn up as a document of stock, analyzing the values at the end of the year, regardless of the infra-annual dynamic formation of the BSS (it is therefore the IS that performs a dynamic analysis of the events of a company). When, for running FRA, we compare the IS (with an infra-annual formation) and the BSS values (calculated at the end of the year), inevitably there is an approximation of the business dynamics, since we are comparing a dynamic result (IS) and a static result (BBS) at the end of the year.

The main measure of profitability is the ROE (return on equity), and it is the first financial ratio applied in this research. This ratio aims to quantify the return on equity contributed by the shareholders of the company. ROE is the main ratio that the shareholders of the company use to quantify the return on their own investment expressed as a nominal return on equity capital during the year due to management. ROE can be expressed as the ratio between net income ( $\Pi)$ and equity capital (E), as follows: $\mathrm{ROE}=\Pi$ :E. $\mathrm{ROE}>0$ is a first-order condition (necessary condition) to provide convenience in business management (if and only if $\mathrm{ROE}<0=>\Pi<0$ ). In order to have convenience in terms of ROE, a second-order condition (necessary and sufficient condition) could also be satisfied, that could be expressed as follows: $\mathrm{ROE}>\mathrm{Ke}>0$, where Ke is the implicit cost $\mathrm{E}$, as the use of the resources made by the shareholders. Ke could be considered as the return on capital that the shareholders could obtain in alternative investments, from which we obtain that minimum ROE ( $\mathrm{ROE}^{\mathrm{min}}$ ) that, as a definition, is equal to $\mathrm{Ke}\left(\mathrm{ROE}^{\mathrm{min}}=\mathrm{Ke}\right)$, that is, the minimum ROE acceptable by shareholders. In order to express the overall profitability of the investment made in the company, it is possible to proceed with the calculation of return on assets (ROA). ROA compares the operating income with the total capital invested in the firm and can then be expressed as the ratio between the earnings before interest and tax $($ EBIT), and the total asset (TA), as follows: ROA = EBIT:TA. ROA expresses the annual percentage yield of each unit of capital invested in an enterprise, regardless of the cost of debt, the income from extraordinary items and the taxes; additionally, the quantification of the implicit cost of using equity is not considered. ROA is therefore a ratio that is particularly used to evaluate the performance of the managers of the company, since it expresses the company's operating performance, apart from: (a) the cost of the capital used; and (b) the financial choices that determine the cost of debt. In order to compare the profitability (ROA) and the cost of debt, we consider a third financial ratio as the express return on debts, i.e., the (ROD). The ratio aims to quantify, in percentage terms, the average cost of debt, that is, the cost of debt for which the company has applied in order to finance the management cycle. ROD could be expressed as the ratio of the balance of financial management (SF) and the net financial position (NFP), as follows: ROD = SF:NFP.

Liquidity ratios require the expression of the balance sheet according to a financial criterion of liquidity; it could be defined as expressing both the active and the passive assets, taking into account the capacity of the assets and liabilities becoming money in time, within and over 12 months, and reclassifying the balance sheet items according to the criteria of liquidity and receivables. The liquidity ratios aim at determining the balance sheet short-term equilibrium, defined as the capacity to cover the short-term financial obligations (current liabilities) via the production of financial liquidity sufficient to meet their debts. These ratios aim at determining the ability of the company to 
support the management cycle in the short term, with particular attention to the comparison between short-term investments (current assets) and the sources of short-term financing (short-term liabilities). Liquidity ratios assess the company's ability to meet its current commitments, i.e., commitments which are conventionally considered to be due within 12 months. The company generally has available assets maturing within 12 months in order to meet the commitments maturing within 12 months; other sources of capital could derive from a new inflow of $\mathrm{E}$ or an increase in NFP. The cash conversion within 12 months of the invested assets allows the company to meet its financial obligations that are due in the same period. Ceteris paribus, a company will be able to meet its short-term commitments only through the conversion of a part of the assets invested in money. The assets invested with a cash conversion time within 12 months are defined as short-time active (invested capital), while the debts to be paid within 12 months are called short-time passive (source of capital). The balance of cash then coincides with a situation in which the conversion into currency of short-time active is able to allow for the payment of the short-time passive. If this does not happen, the company must meet its financial commitments by increasing its borrowing or by raising additional capital to make the payments, if this is possible. Another possibility is to request additional capital contributions from equity holders in the form of immediate liquids, to be forced to convert a portion of its fixed assets into cash (i.e., divesting part of its investments in fixed assets), or, finally, to defer part of the expected payments due within 12 months. All these solutions, with the exception of increasing equity capital by the shareholders (if possible) result in a worsening of the balance sheet situation, given an increase in the risk of instability. We can consider, for example, a situation in which a business defers a part of the payments to suppliers because of its inability to access the necessary monetary resources. In this situation, the company is exposed to the risk of default as a result of legal action by the borrower, to recover their debts. In the short term, the equilibrium of the business cycle is expressed by the current liquidity ratio, calculated as the ratio of short-term investments and current liabilities; this ratio is defined by the current ratio $(\mathrm{CR})$ and is calculated as the ratio of short-term activities and liabilities, as follows: $C R=\left(C L+W C i^{T}\right): D^{M<12}$, where $D^{M<12}=D^{<12 m}+D w c^{a p<12 m}+D w c^{0<12 m}$. The ratio expresses the company's ability to meet its financial commitments due within 12 months via the conversion of the assets invested in money that are payable within 12 months; a situation where $C R>1$ expresses the company's short-term financial equilibrium, as the firm is able to cover its maturing commitments in the short period (within 12 months) by converting a part of its assets to currency (active voices of the balance sheet); if $C R<1$, we have a situation in which the enterprise has difficulties in covering short time obligations by converting its current assets into money. In the event that $\mathrm{CR}=1$ we have a balance between the short-time assets and liabilities. It is also possible to express $\mathrm{CR}$ in terms of the balance being expressed not as a percentage but directly in terms of monetary value. In this case, the margin available for paying the debts due within 12 months is analyzed using the active voices of the balance sheet; this margin takes the name of net working capital (NWC). If NWC $>0$, the company is able to meet its obligations, due within 12 months, since it has financial sustainability within the business cycle in the short term; but if $\mathrm{NWC}<0$, the company is unable to meet its obligations due within 12 months and will have to use additional sources of funding; or it will have to defer a part of the payments in order to support the business cycle in the short term. For the analysis of liquidity, an additional ratio that is more restrictive is used; this ratio is the quick ratio $(\mathrm{QR})$ and is the ratio between short-term investments $\left(\mathrm{CL}+\mathrm{WCi}^{\mathrm{T}}\right)$, the net of inventories $\left(C w c^{\mathrm{i}}\right)$, and short-term liabilities $\left(\mathrm{D}^{\mathrm{M}<12}\right)$ expressing means current liabilities; the ratio is expressed as follows: $\mathrm{QR}=\left(\mathrm{CL}+\mathrm{Cwc}^{\mathrm{ar}<12 \mathrm{~m}}+\mathrm{Cwc}^{\mathrm{o}<12 \mathrm{~m}}+\mathrm{CwC}^{\mathrm{q}}\right): \mathrm{D}^{\mathrm{M}<12}$. QR expresses the evaluation of the sustainability of a short-term business cycle, applying a more conservative approach than that shown in CR. This approach highlights the fact that part of the inventory could not be immediately sold, or it can only be sold in part because it is not possible to go under a minimum stock level of inventories. Finally, amongst the capital ratios, we consider the debt equity ratio (DER), calculated as the ratio of total $\left(\mathrm{D}^{\mathrm{T}}\right)$ and equity $(\mathrm{E})$, as follows: $\mathrm{DER}=\mathrm{D}^{\mathrm{T}}$ :E. DER expresses the level of indebtedness, taking into account the degree of use of debt capital for the financing of the firm; DER is perhaps the most 
important financial ratio that is applied to quantify the financial strength of a firm's capital structure. The ratio variation ranges between 0 and $+\infty$, if $0 \leq \mathrm{DER}<1=>\mathrm{E}>\mathrm{D}^{\mathrm{T}}$, if $\mathrm{DER}=1=>\mathrm{D}^{\mathrm{T}}=\mathrm{E}$, and if $1<\mathrm{DER}<+\infty=>\mathrm{D}^{\mathrm{T}}>\mathrm{E}$; one should therefore note that a gradual increase in the value of DER expresses an increase in the level of debt among the company's sources of financing, that is, detrimental to $\mathrm{E}$. This situation shows a gradual reduction in the level of strength that a company's balance sheet has for increasing the use of third-party funds for the financing of investments. Additionally, the situation in which DER $<0$ is theoretically possible; this situation implies that ET assumes a negative value, expressing the necessity for the equity holders to immediately give new equity capital for the financing of the company, or to declare a state of default.

To quantify the duration (in days) of a financial cycle, financial ratios that express the length of the NWC financial cycle are currently applied; there are three main financial ratios for the NWC duration: (1) AR_DAYS, calculated as follows: AR_DAYS $=\left(C w c^{\mathrm{ar}}<12 \mathrm{~m}+\mathrm{Cwc} \mathrm{c}^{\mathrm{ar}>12 \mathrm{~m}}\right) \times 365: \mathrm{S}$; this expresses the length of the payment deferral given to clients, in days; (2) AP_DAYS, calculated as follows: AP_DAYS $=\left(D_{w c} c^{a p<12 m}+D_{w c} c^{a p>12 m}\right) \times 365: S$; this expresses the length of the payment given by suppliers in days; (3) INV_DAYS, calculated as follows: INV_DAYS $=W C \mathrm{i}^{\mathrm{i}} \times 365: S$; this expresses the length of inventory rotation in days. AR_DAYS + INV_DAYS - AP_DAYS = NWC_DAYS, where NWC_DAYS is the length of the NWC in days. An increase in AR_DAYS and INV_DAYS, and a decrease in AP_DAYS (thus expressing an increase of the NWC cycle duration, which is given by an increase in the NWC_DAYS value) determine an increase in the capital investment that is to be forcibly financed with debt $\left(\mathrm{D}^{\mathrm{T}}\right)$ or equity $(\mathrm{E})$ capital.

\section{Results and Discussion}

\subsection{Overview of Firm Characteristics in the Tomato Sector}

In 2016, about 38 million tons of tomatoes were processed worldwide with an increase of about $14 \%$ from 2012. Italy, with 5.2 million tons of processed tomatoes, is the second biggest processor in the world, after the USA, and represents $14 \%$ of the world production, with a total turnover of over 3.1 billion euros. About $60 \%$ of the national production is destined for the foreign market, both Europe (Germany, France, UK) and other countries (USA, Japan, Australia), with an export value of 1.6 billion euros. Tomato production in Italy (Table 1) decreased by 31.71\% from 2007 to 2016; this reduction in production is greater in tomatoes produced for food consumption $(-22.27 \%)$ than in tomatoes produced for the processing industry $(-16.70 \%)$.

Table 1. Tomato production in Italy (2007-2016) *.

\begin{tabular}{cccc}
\hline Year & Tomato for Food Consumption (Ha) & Tomato for Processing Industry (Ha) & Total Tomato (Ha) \\
\hline 2007 & 23,401 & 94,346 & 117,747 \\
2008 & 19,806 & 88,389 & 108,195 \\
2009 & 19,314 & 96,768 & 116,082 \\
2010 & 19,679 & 94,514 & 114,193 \\
2011 & 19,409 & 84,449 & 103,858 \\
2012 & 16,325 & 75,525 & 91,850 \\
2013 & 19,384 & 68,900 & 88,284 \\
2014 & 18,418 & 77,539 & 95,957 \\
2015 & 18,072 & 81,669 & 99,741 \\
2016 & 18,190 & 78,592 & 96,782 \\
\hline
\end{tabular}

* National Institute of Statistics of Italy (ISTAT, Istituto Nazionale di Statistica); data available at: [43]

In the same period (Table 2), there was an increase in the production of tomatoes for processing (3.32\% for production and $3.76 \%$ for harvesting), with an increase in average yields per hectare, while the production of tomatoes for food consumption decreased by $26.22 \%$ and $28.49 \%$ in harvesting. 
Table 2. The production of tomatoes in Italy (2007-2016) *.

\begin{tabular}{ccccccc}
\hline Year & $\begin{array}{c}\text { Tomato for Food } \\
\text { Consumption } \\
\text { Production (Ton.) }\end{array}$ & $\begin{array}{c}\text { Tomato for } \\
\text { Processing } \\
\text { Industry } \\
\text { Production (Ton.) }\end{array}$ & $\begin{array}{c}\text { Total Tomato } \\
\text { Production } \\
\text { (Ton.) }\end{array}$ & $\begin{array}{c}\text { Tomato for Food } \\
\text { Consumption } \\
\text { Harvesting (Ton.) }\end{array}$ & $\begin{array}{c}\text { Tomato for } \\
\text { Processing } \\
\text { Industry } \\
\text { Harvesting (Ton.) }\end{array}$ & $\begin{array}{c}\text { Total Tomato } \\
\text { Harvesting } \\
\text { (Ton.) }\end{array}$ \\
\hline 2007 & 757,557 & $5,420,894$ & $6,178,451$ & 744,027 & $5,260,753$ & $6,004,780$ \\
2008 & 619,750 & $4,979,199$ & $5,598,949$ & 604,993 & $4,870,202$ & $5,475,195$ \\
2009 & 602,084 & $6,078,048$ & $6,680,132$ & 576,493 & $5,918,090$ & $6,494,583$ \\
2010 & 649,360 & $5,125,754$ & $5,775,114$ & 631,429 & $4,997,146$ & $5,628,575$ \\
2011 & 635,929 & $5,471,195$ & $6,107,124$ & 619,385 & $5,330,830$ & $5,950,215$ \\
2012 & 489,635 & $4,792,568$ & $5,282,203$ & 460,651 & $4,671,325$ & $5,131,976$ \\
2013 & 593,535 & $4,459,833$ & $5,053,368$ & 567,207 & $4,321,568$ & $4,888,775$ \\
2014 & 543,842 & $4,714,067$ & $5,257,909$ & 490,206 & $4,609,269$ & $5,099,475$ \\
2015 & 576,157 & $5,528,588$ & $6,104,745$ & 528,276 & $5,365,683$ & $5,893,959$ \\
2016 & 558,951 & $5,600,839$ & $6,159,790$ & 532,069 & $5,458,447$ \\
\hline
\end{tabular}

* National Institute of Statistics of Italy (ISTAT, Istituto Nazionale di Statistica); data available at: [43]

The production and processing of tomatoes in Italy dates back to the 19th century. The production of the tomato is destined partly for the consumption of fresh product and partly for the production of vegetable preserves, such as tomato concentrate, juices and tomato pulp for consumption or as a condiment on pasta, pizza or other foods. In Italy, there are two major production areas, one in southern Italy, particularly in the regions of Campania and Basilicata (as well as in Sicilia region), and another in the Po Valley, particularly in the Emilia-Romagna, Lombardia and Piemonte regions.

The Po Valley is a morphologically and hydrographically unitary alluvial plain situated in southern Europe that extends along northern Italy, including the Po river basin, which comprises parts of the Piemonte, Lombardia, Emilia-Romagna and Veneto regions, including all areas within about $100 \mathrm{~m}$ above sea level. The Po Valley, which covers about $47,000 \mathrm{~km}^{2}$, is bathed by the Po and its many tributaries, as well as the Adige, Brenta, Piave, Tagliamento and Reno rivers. The Po Valley is one of the largest European plains and is the largest in southern Europe; it occupies most of northern Italy, from the Western Alps to the Adriatic Sea. The Po river is almost in the center of the valley and crosses it in a west-east direction. The climate is characterized by a wide annual temperature range, with low average temperatures in winter close to zero degrees Celsius and high temperatures in summer, sometimes above 30 degrees Celsius One of the characteristics of the Po Valley climate, common to the entire plain, is the scarcity of ventilation, which in summer makes the days hot and sultry. About 20 million people live in the Po Valley, equal to about a third of the Italian population living in an area that accounts for about $15 \%$ of Italy's land area. The Po Valley has a vast concentration of agricultural and industrial activities and is one of the largest production hubs in the European Union, with one of the highest per capita incomes and greatest concentration of industrial and agricultural activity.

In Italy, the most important tomato production area (Table 3) includes the regions of EmiliaRomagna, Lombardia, Veneto, and Piemonte. This area produced over 2.7 million tons in 2016 (about $50 \%$ of the domestic production of tomatoes). The second main production area is in the southern part of Italy, including the regions of Campania, Puglia, Calabria and Basilicata, where the production was about 2.3 million tons in 2016 (about $43 \%$ of the domestic production).

In the last ten years, the tomato processing sector in northern Italy has been the subject of a major crisis. In fact, progressive concentration of the sector has been observed, with a reduction in the number of operating firms. The possible causes are many. First, smaller firms, as shown in the study, are characterized by lower profitability and greater levels of financial dependence on the credit system, with a consequent increase in the cost of financial capital. This has encouraged the merger of smaller firms with larger groups, and in some cases, there have been firm closures following bankruptcy or compulsory liquidation. Smaller firms have little access to economies of scale in the acquisition of production factors, in production efficiency and in access to financial capital. Moreover, smaller firms are often not able to market products under their own brands, thus suffering from the bargaining power of large food distribution firms. Small firms are not able to adequately promote their products 
with advertising investments and/or new technologies, or even to sell products on foreign markets, due to language barriers, scarcity of personnel available for the development of commercial campaigns abroad or inability to manage international law. In northern Italy alone, over the past 10 years, at least nine closures of tomato processing firms have been registered, of which five closed due to bankruptcies or compulsory liquidations.

Table 3. The surface, production and yield of processing tomatoes in Italy, by region (2016) *

\begin{tabular}{|c|c|c|c|c|}
\hline Region & Surface (Ha) & $\begin{array}{l}\text { Tomato for Processing } \\
\text { Industry Production (Ton.) }\end{array}$ & $\begin{array}{l}\text { Tomato for Processing } \\
\text { Industry Harvesting (Ton.) }\end{array}$ & Yield (Ton./Ha) \\
\hline Piemonte & 1202 & 63,924 & 63,812 & 53.18 \\
\hline Valle d'Aosta & - & - & - & - \\
\hline Lombardia & 7971 & 538,755 & 538,755 & 67.59 \\
\hline Liguria & - & - & - & - \\
\hline $\begin{array}{l}\text { Trentino-Alto } \\
\text { Adige }\end{array}$ & 6 & 150 & 150 & 25.00 \\
\hline Veneto & 2007 & 124,324 & 105,674 & 61.95 \\
\hline $\begin{array}{c}\text { Friuli-Venezia } \\
\text { Giulia }\end{array}$ & 4 & 128 & 128 & 31.90 \\
\hline Emilia-Romagna & 26,456 & $2,015,616$ & $2,015,616$ & 76.19 \\
\hline Toscana & 2122 & 137,661 & 135,373 & 64.87 \\
\hline Umbria & 267 & 14,560 & 14,560 & 54.53 \\
\hline Marche & 25 & 1041 & 987 & 41.64 \\
\hline Lazio & 2078 & 94,100 & 84,900 & 45.28 \\
\hline Abruzzo & 1110 & 53,122 & 53,060 & 47.86 \\
\hline Molise & 600 & 36,000 & 36,000 & 60.00 \\
\hline Campania & 4083 & 265,456 & 257,389 & 65.01 \\
\hline Puglia & 20,480 & $1,907,500$ & $1,811,780$ & 93.14 \\
\hline Calabria & 2849 & 124,899 & 120,415 & 43.84 \\
\hline Basilicata & 2244 & 127,305 & 125,550 & 56.73 \\
\hline Sicilia & 4680 & 67,740 & 65,740 & 14.47 \\
\hline Sardegna & 408 & 28,560 & 28,560 & 70.00 \\
\hline ITALY & 78,592 & $5,600,840$ & $5,458,448$ & 71.26 \\
\hline
\end{tabular}

* National Institute of Statistics of Italy (ISTAT, Istituto Nazionale di Statistica); data available at: [44]

Even today, the processing of tomatoes generally operates near the areas of production because of cost reduction. The Organizzazione Interprofessionale Inter Regionale, “OI Pomodoro da Industria Nord Italia (The Inter-regional Interprofessional Organization) has operated in northern Italy since 2011. This is a non-profit organization that brings together the economic players in the tomato production chain in the regions of Emilia-Romagna, Lombardia, Piemonte, Veneto and the autonomous province of Bolzano. In this area, every year about 38 thousand hectares of tomatoes are cultivated with the involvement of about two thousand agricultural producers (grouped in 14 Op, producer organizations) and 29 processing plants (headed by 22 different companies) for the processing of about 2.6 million tons of tomato [45]. The first activities of the OI Pomodoro da Industria of northern Italy took place in 2006 and involved the Distretto del Pomodoro da Industria del Nord Italia companies and producers' organizations in the Province of Parma, Piacenza and Cremona (Emilia-Romagna and Lombardia Regions). The association was at the center of a progressive expansion and achieved formal recognition as an Inter-regional OI in December 2011, thanks to the 24/2000 law of the Emilia-Romagna Region. Since a 2013 campaign, 29,175 hectares have been cultivated in the district. The production of 1,879,993 tons, produced by the 15 associations of the Associated Producers, has been transformed by 25 processing companies, in 30 factories located across the territory, and subdivided into private companies (60\%) and cooperative enterprises (40\%). Ninety six percent of the tomatoes are grown as part of an integrated production, while the remaining $4 \%$ come from organic farming. The fresh tomatoes are transformed into $36 \%$ tomato concentrates (semi, concentrated, double or triple), $36 \%$ pulp (cubed, fine or extruded), 27\% tomato paste and 1\% ready-made sauces [46]. tomato processing firms therefore remains concentrated in two major districts, one in the north of the country and one in the south. In the northern district, located in the Po Valley (in particular in the territories of Emilia and southern Lombardia Regions), which we consider in this research, 21 processing firms (of which 16 are limited firms and 5 are cooperatives) and 16 Producer Organizations (OP) operate. This is a reduction 
of nine firms in 2011 when 30 tomato processing firms were operating in the northern district. In the southern district 70 processing firms and 30 OP operate, again with a reduction of 49 firms from 2011 when 119 tomato processing firms operated in the southern district.

Since the change in inventory and the sales that are not yet collected affect the positive value of production on company profit, there is the possibility of mismatches between profit and cash flow in the firms in the sector, with situations in which firms, even those that are profit positive, are unable to support payments in the financial cycle. In the tomato sector, traditional firms have production plants with processing spaces on several floors of the plant, which are often not modernized. There are also firms that have invested in property, plants and machinery to increase their production efficiency; these firms are typically characterized as belonging to large groups, or as operating on higher production volumes, which are able to operate on a larger scale of production, with advantages in terms of reducing the cost of production per unit. Therefore, firms in the sector need a large amount of capital in order to finance investments in fixed assets (FA), in terms of property, plants and machinery, and in net working capital (NWC), including the finished product stocks at the end of the production phase in the summer. These funds are obtained either directly by the entrepreneur as equity capital (E), or as debt capital $\left(\mathrm{D}^{\mathrm{T}}\right)$. Debt capital may be implicitly burdensome, as in the case of commercial debts, or they may be on an explicit charge, as in the case of bank debt. Since the size of the firms in the sector are mainly small and medium enterprises (SME), it is important to apply financial ratios in order to evaluate their financial performance. In fact, SMEs often have the worst access to the equity capital market and to the debt capital market (bank debt, structured finance, syndicated loans, etc.), as highlighted by various studies [47-51]. Generally speaking, for the financing of investments in property, plant and equipment, the firms in the sector use, in addition to equity capital (E), long-term bank loans and real estate leasing generally articulated in the form of mortgages with a guarantee on real estate property and, less frequently, as an unsecured form. In this last case, durations are reduced and often collateral security with a pledge or guarantee of signature is requested and often given by members or credit guarantee consortia. For the financing of working capital, firms favor short-term lines of finance, such as advances on trade receivables, advances on contracts and advances on consignments of raw materials that are to be transformed. In medium-long term loans, on the basis of an amortization plan, firms have a contractual obligation to repay the contract debt increased by the interest expense (debt service), while in the case of short-term forms of financing, firms after paying the cost of the debt, proceed to the principal repayment of the loan obtained through the monetization of the sale of assets of the working capital acquired through short-term loans once the trade receivables have been collected. the assessment of the sustainability of the debt service and the financial sustainability of the business cycle is therefore relevant, and could be calculated if the proper financial ratios were applied.

\subsection{Data Collection and Research Plan}

Our research aimed to analyze the financial data of a sample of tomato processing firms operating in the northern district. These firms operate in the transformation of tomatoes, as raw material, into finished products. Data analysis compared the data of the distressed firms ( 5 distressed firms) with the data of others firm samples (12 not-distressed firms) in order to define significant differences in management performance between the two groups (distressed and not-distressed firms) as evidenced by financial ratio values. In the research plan, we consider "distressed" firms subjected to a formal bankruptcy procedure, during the period ranging from 2007 to 2016; the concept of bankruptcy (default) procedure considered here is as defined in the Italian Bankruptcy Law (Text of the Royal Decree of 16 March 1942, No. 267, Bankruptcy Law, containing the discipline of bankruptcy, of the arrangement with creditors, of the controlled administration and of the compulsory administrative liquidation).

The data analysis of firms in the sector of industrial tomato processing was done on the basis of the data of public filings with the Registrar of Firms for the years 2007 to 2016, for a sample of 17 firms. The data covers the two last years of annual account data for five as-defined-before distressed 
companies (before the firms' default), with a total of 10 years of data, and it covers two years of annual account data (randomly chosen in the period from 2007 and 2016), for the 12 not-distressed firms considered in the sample, with a total of 24 years of data. The data was derived from the "Computerized analysis of Italian firms" database (AIDA). The data analysis was performed with a SPSS statistical package (issue 19). Our analysis was developed as follows: (a) we reclassified the AAS of 17 firms (5 distressed firms and 12 not-distressed firms) included in the sample, applying descriptive statistics to BSS and IS, exposing balance sheets and income statements in percentage values (as a percentage of TA and S, respectively); (b) we calculated the financial ratios as exposed in the methodological part of the article; (c) we tested whether there are statistically significant differences between the patrimonial values of BSS in distressed and not-distressed firms; (d) we tested whether there are statistically significant differences between the economic margins of IS in distressed and not-distressed firms; and (e) we tested whether there are statistically significant differences between the financial ratios in distressed and not-distressed firms.

\subsection{Annual Account Data Analysis}

We started the data analysis by reclassifying the AAS of 17 firms applying descriptive statistics to BSS, IS, CFS and FR. The analysis of the 17 sample firms first considered the BSS data (Table 4) for 12 not-distressed firms (24 years of data) and for 5 distressed firms (10 years of data). In particular, for not-distressed firms the capital absorption is in fixed assets (the mean value of BFA is $86.20 \%$ of TA), and this confirms that processing firms are characterized by investments in fixed assets, particularly for $\mathrm{Bfa}^{\tan }(40.31 \%$ of TA). BFA investments have an effect on the increase of capital needed to finance long-term investments covered with ET or $\mathrm{Df}^{>12 \mathrm{~m}}$. To cover investments in BFA, not-distressed firms in the sample use financial debt $\left(\mathrm{Df}^{>12 \mathrm{~m}}+\mathrm{Df}^{<12 \mathrm{~m}}\right)$ as the first source of capital, given the fact that, respectively, $\mathrm{Df}^{>12 \mathrm{~m}}+\mathrm{Df}^{<12 \mathrm{~m}}$ are $14.93 \%$ and $27.66 \%$ of TA; $\mathrm{E}$ is $32.41 \%$, which confirms its importance as the second source of capital. Stable sources of capital $\left(E+\mathrm{Df}^{>12 \mathrm{~m}}\right)$ are $60.07 \%$ of TA, while BFA is $45.23 \%$ of TA; additionally, stable sources of finance are not able, in mean values, to completely cover the financial needs to finance BFA investments. In the cycle of working capital, $\mathrm{Cwc} \mathrm{c}^{\mathrm{ar}<12 \mathrm{~m}}(26.66 \%$ of $\mathrm{TA})$ and $\mathrm{CWC}^{\mathrm{i}}(22.29 \%$ of TA) prevail.

Concerning distressed firms, financial debt $\left(\mathrm{Df}^{>12 \mathrm{~m}}+\mathrm{Df}^{<12 \mathrm{~m}}\right)$ is the second source of capital, given the fact that, respectively, $\mathrm{Df}^{>12 \mathrm{~m}}+\mathrm{Df}^{<12 \mathrm{~m}}$ are $12.73 \%$ and $16.46 \%$ of TA; in fact, the first source of capital is given by commercial credit, given that $\mathrm{Dwc}^{\mathrm{ap}<12 \mathrm{~m}}$ amounts to $45.14 \%$ of TA, and this expresses the massive recourse to commercial credit in order to cover the investment cycle. Even if it is not possible to achieve a complete response to the matter, such an intensive use of commercial credit could be hiding a difficulty in accessing financial debt (given the not-positive state of the AAS, as ictu oculi emerges from financial data of the distressed firms) or situations that risk legal action on the part of suppliers to recover their credits, which would probably be past due (expired credits). In the distressed firms samples, $\mathrm{E}$ is only $3.41 \%$ of TA, expressing a high level of indebtedness in terms of financial debt $\left(\mathrm{Df}^{>12 \mathrm{~m}}+\mathrm{Df}^{<12 \mathrm{~m}}\right)$ and credit, given that $\mathrm{Dwc}^{\mathrm{ap}<12 \mathrm{~m}}$; the stable sources of capital $\left(\mathrm{E}+\mathrm{Df}^{>12 \mathrm{~m}}\right)$ are $19.87 \%$ of TA, while BFA is $22.14 \%$ of TA, given that a part of FA investments is financed with short-term debt, which expresses a typical state of financial risk. In the cycle of working capital, $C w c^{a r}<12 \mathrm{~m}$ ( $40.56 \%$ of TA) and $C w c^{\mathrm{i}}\left(30.68 \%\right.$ of TA) prevail. Such a high level of $w c^{\mathrm{ar}<12 \mathrm{~m}}$ and $\mathrm{CWc}^{\mathrm{i}}$ are notable, because these values may overestimate the real value of credits and inventories stock, not considering the losses on credits, or definitively, the manipulation of accounting values with false accounting entries. An analysis of BSS shows that the Kolmogorov-Smirnov D statistic on normality of distribution highlights that BSS data do not follow a normal distribution. Applying descriptive statistics, analysis shows that distressed firms have a reduced portion of TS that is financed with E, thus confirming the increase in the level of risk when equity capital reduces its weight between the sources of capital; this result is consistent with the literature [52]. It is necessary to clarify that the increase in risk is not only potentially damaging for equity holders (particularly when their provision in terms of $\mathrm{E}$ is highly reduced) but that it is a greater risk for debt holders, whose expectations of 
repayment could be frustrated by the default of the firms (in fact, the damage in absolute value for equity holders will be progressively reduced with a decreasing value of $E$ as a source of capital). As in this case of the tomato processing sector, the damage by distressed firms to debt holders appears to be particularly relevant (even in terms of unemployment and tax damage resulting from the non-payment of taxes by distressed firms). It is interesting to note that distressed firms in the tomato sector have TS similar to that of not-distressed firms, suggesting that firms with a higher dimension are not as subject to bankruptcy risks.

Table 4. The balance sheet data of the sample firms (not-distressed and distressed firms) with the reclassification of the balance sheets with financial forms, and an approach derived from Equation (1).

\begin{tabular}{|c|c|c|c|c|}
\hline Value & $\begin{array}{c}\text { Mean (€) } \\
\text { Not-Distressed Firms }\end{array}$ & $\begin{array}{c}\text { Mean (\% TA) } \\
\text { Not-Distressed Firms }\end{array}$ & $\begin{array}{c}\text { Mean }(€) \\
\text { Distressed Firms }\end{array}$ & $\begin{array}{c}\text { Mean (\% TA) } \\
\text { Distressed Firms }\end{array}$ \\
\hline $\mathrm{A}$ & - & - & - & - \\
\hline $\mathrm{Bfa}^{\text {int }}$ & $1,122,550$ & $4.76 \%$ & 656,550 & $5.06 \%$ \\
\hline $\mathrm{Bfa}^{\tan }$ & $9,505,952$ & $40.31 \%$ & $2,132,251$ & $16.42 \%$ \\
\hline $\mathrm{Bfa}^{\text {fin }}$ & 36,925 & $0.16 \%$ & 85,920 & $0.66 \%$ \\
\hline BFA & $10,665,427$ & $45.23 \%$ & $2,874,721$ & $22.14 \%$ \\
\hline $\mathrm{CWC}^{\mathrm{ar}<12 \mathrm{~m}}$ & $6,285,992$ & $26.66 \%$ & $5,265,321$ & $40.56 \%$ \\
\hline $\mathrm{CWc}^{\mathrm{ar}>12 \mathrm{~m}}$ & 432,025 & $1.83 \%$ & 69,859 & $0.54 \%$ \\
\hline $\mathrm{CWC}^{\mathrm{o}<12 \mathrm{~m}}$ & 238,220 & $1.01 \%$ & 663,669 & $5.11 \%$ \\
\hline $\mathrm{Cwc}^{\mathrm{o}>12 \mathrm{~m}}$ & 12,501 & $0.05 \%$ & 26,336 & $0.20 \%$ \\
\hline $\mathrm{CW}^{\mathrm{ci}}$ & $5,256,005$ & $22.29 \%$ & $3,982,336$ & $30.68 \%$ \\
\hline $\mathrm{Cwc}^{\mathrm{ql}}$ & 9824 & $0.04 \%$ & 1033 & $0.01 \%$ \\
\hline CL & 659,223 & $2.80 \%$ & 32,652 & $0.25 \%$ \\
\hline $\mathrm{D}$ & 23,321 & $0.10 \%$ & 65,993 & $0.51 \%$ \\
\hline TA & $23,582,538$ & $100.00 \%$ & $12,981,920$ & $100.00 \%$ \\
\hline $\mathrm{AE}^{\mathrm{sc}}$ & $2,320,221$ & $9.84 \%$ & 510,252 & $3.93 \%$ \\
\hline $\mathrm{AE}^{\mathrm{r}}$ & $1,985,622$ & $8.42 \%$ & 165,220 & $1.27 \%$ \\
\hline $\mathrm{AE}^{\Pi}$ & $2,133,221$ & $9.05 \%$ & 20,552 & $0.93 \%$ \\
\hline $\mathrm{A} \Pi$ & $1,203,834$ & $5.10 \%$ & 112,578 & $0.87 \%$ \\
\hline $\mathrm{E}$ & $7,642,898$ & $32.41 \%$ & 442,342 & $3.41 \%$ \\
\hline B & 252,130 & $1.07 \%$ & 23,025 & $0.18 \%$ \\
\hline $\mathrm{C}$ & 796,220 & $3.38 \%$ & 320,221 & $2.47 \%$ \\
\hline $\mathrm{Df}^{<12 \mathrm{~m}}$ & $3,521,002$ & $14.93 \%$ & $1,653,200$ & $12.73 \%$ \\
\hline $\mathrm{Df}^{>12 \mathrm{~m}}$ & $6,523,201$ & $27.66 \%$ & $2,136,630$ & $16.46 \%$ \\
\hline$D w c^{a p<12 m}$ & $3,812,412$ & $16.17 \%$ & $5,859,687$ & $45.14 \%$ \\
\hline$D w c^{a p>12 m}$ & 120,330 & $0.51 \%$ & 262,022 & $2.02 \%$ \\
\hline $\mathrm{Dwc}^{\mathrm{o}<12 \mathrm{~m}}$ & 713,647 & $3.03 \%$ & $1,663,215$ & $12.81 \%$ \\
\hline $\operatorname{Dwc}^{\mathrm{o}>12 \mathrm{~m}}$ & 50,336 & $0.21 \%$ & 62,135 & $0.48 \%$ \\
\hline D- & 150,362 & $0.64 \%$ & 559,443 & $4.31 \%$ \\
\hline $\mathrm{D}^{\mathrm{T}}$ & $15,939,640$ & $67.59 \%$ & $12,539,578$ & $96.59 \%$ \\
\hline TS & $23,582,538$ & $100.00 \%$ & $12,981,920$ & $100.00 \%$ \\
\hline
\end{tabular}

In the not-distressed firms samples (Table 5), the mean value of $S$ amounts to $€ 26,523,211$, and the major production factors are raw materials (Mc) $(14,215,333,53.60 \%$ of $S)$ and services (Sc) $(3,862,025$, $14.56 \%$ of S). EBITDA has a mean value of $4,601,746$ (17.35\% of S). Ac + Dc absorbs a mean value of about 8 per cent of S, and EBIT then has a mean value of 2,548,474 (9.61\% of S). Financial management (SF) absorbs a mean value $1.63 \%$ of $S$ (that is lower than EBITDA and EBIT, expressing the capacity of these income margins to pay the cost of debt); $\Pi$ has a mean value of $1,203,834(4.54 \%$ of $S)$, and $\Pi \geq 0$ in 22 cases out of 24 . It is useful to note that 2 cases of negative $\Pi$ are concentrated in one firm. Kolmogorov-Smirnov D statistic on normality of distribution shows that IS data do not follow a normal distribution. In distressed firms' samples, the mean value of $S$ amounts to 6,593,220 (largely lower than in not-distressed firms sample); raw materials (Mc) remain the most important production factors $(4,102,220,62.22 \%$ of $S)$, as do services (Sc) $(956,203,14.50 \%$ of $S)$. EBITDA has a mean value of 775,969 (11.77\% of $S$, and lower than in not-distressed firms samples), and EBIT has a mean value of 115,485 (1.75\% of S, again lower than in not-distressed firms samples). Financial management (SF) absorbs a mean value of $3.98 \%$ of $\mathrm{S}$ (which is higher than EBIT, expressing the incapacity of the EBIT 
margin to pay the cost of debt); $\Pi$ has a mean (negative) value of $112,578(1.49 \%$ of S), and $\Pi<0$ in 8 cases out of 10. An analysis of IS also shows that the Kolmogorov-Smirnov D statistic on normality of distribution highlights that IS data do not follow a normal distribution. The analysis, applying descriptive statistics, shows by event-analyzing IS, that not-distressed firms in the tomato sector have a higher dimension (in this case, considering $\mathrm{S}$ ) than the distressed firms, suggesting that firms with a higher dimension are less subject to bankruptcy risks. Following this, the matter could be usefully studied in future research by extending the sample data to the entire tomato processing sector in Italy, as well as in other EU countries.

Table 5. The income statement data of the sample firms (not-distressed and distressed firms) with the reclassification of income statements using a value-added approach derived from Equation (2).

\begin{tabular}{ccccc}
\hline Value & $\begin{array}{c}\text { Mean (€) } \\
\text { Not-Distressed Firms }\end{array}$ & $\begin{array}{c}\text { Mean (\% S) } \\
\text { Not-Distressed Firms }\end{array}$ & $\begin{array}{c}\text { Mean (€) } \\
\text { Distressed Firms }\end{array}$ & $\begin{array}{c}\text { Mean (\% S) } \\
\text { Distressed Firms }\end{array}$ \\
\hline S & $26,523,211$ & $100.00 \%$ & $6,593,220$ & $100.00 \%$ \\
$\Delta$ Cwc $^{\mathrm{i}}$ & 903,220 & $3.41 \%$ & 966,320 & $14.66 \%$ \\
Cp & 12,533 & $0.05 \%$ & 32,652 & $0.50 \%$ \\
Os & 423,205 & $1.60 \%$ & 105,363 & $1.60 \%$ \\
Mc & $14,215,333$ & $53.60 \%$ & $4,102,220$ & $62.22 \%$ \\
Sc & $3,862,025$ & $14.56 \%$ & 956,203 & $14.50 \%$ \\
Rc & $1,292,330$ & $4.87 \%$ & 565,321 & $8.57 \%$ \\
Lc & $3,205,630$ & $12.09 \%$ & 985,622 & $14.95 \%$ \\
Oc & 685,105 & $2.58 \%$ & 312,220 & $4.74 \%$ \\
EBITDA & $4,601,746$ & $17.35 \%$ & 775,969 & $11.77 \%$ \\
Dc & $1,923,020$ & $-0.25 \%$ & 562,250 & $8.53 \%$ \\
Ac & 130,252 & $-0.49 \%$ & 98,234 & $1.49 \%$ \\
EBIT & $2,548,474$ & $9.61 \%$ & 115,485 & $1.75 \%$ \\
SF & 432,033 & $-0.63 \%$ & 262,2520 & $3.98 \%$ \\
SR & 13,205 & $-0.05 \%$ & 10,252 & $0.16 \%$ \\
SX & 132,620 & $0.50 \%$ & 36,257 & $0.55 \%$ \\
$\Pi^{\mathrm{bT}}$ & $2,235,856$ & $8.43 \%$ & 100,258 & $1.52 \%$ \\
T & $1,032,022$ & $3.89 \%$ & 12,320 & $0.19 \%$ \\
$\Pi$ & $1,203,834$ & $4.54 \%$ & 112,578 & $1.71 \%$ \\
\hline
\end{tabular}

\subsection{Financial Ratio Analysis}

In Table 6, we calculated the ratios as outlined in the methodological part of the article. The analysis shows that the not-distressed firms are characterized by better performance ratios. In fact, ROE is positive for not-distressed firms $(15.75 \%)$ while it is negative $(25.45 \%)$ for distressed firms. The result of ROA is even greater, which is $10.81 \%$ for not-distressed firms and $0.89 \%$ for distressed firms; this ratio, which makes it possible to calculate the profitability of operating activities, shows that distressed firms are not able to generate profitability (ROA just over zero) and that the cost of debt (ROD of 6.98\%) is higher than ROA. Distressed firms are not able to use leverage which, as is known, is possible if and only if ROA $>$ ROD, thus expressing that the operating return of the capital (ROA) is higher than the cost of debt (ROD). Given the outcome of the analysis, we did not take into account the tax shield generated by the deduction of the cost of the debt, which at present is not relevant, given the losses recorded for distressed firms. Even the not-distressed firms, show a high cost of debt ( $\mathrm{ROD}=4.60 \%$ as mean value) which erodes about $42 \%$ of the operating profitability generated by management (ROD:ROA $=0.4255)$. As regards the liquidity ratios $(C R$ and $Q R)$, the analysis shows that $\mathrm{CR}$ is greater than 1 both for not-distressed and distressed firms, and that $\mathrm{QR}$ is substantially equal ( 0.65 and 0.62$)$ in the two analyzed firm samples. On the other hand, it is clear that the distressed firms have a much higher level of debt (DER) than the not-distressed firms (DER are respectively at 28.35 and 2.09); the DER shows a very high level of indebtedness. It should be noted that in the case of distressed firms $C R$ and $Q R$ do not have values considered to be of high risk [53-57]. 
Table 6. A ratio analysis of the sample firms (not-distressed and distressed firms).

\begin{tabular}{ccc}
\hline Value & $\begin{array}{c}\text { Mean } \\
\text { Not-Distressed Firms }\end{array}$ & $\begin{array}{c}\text { Mean } \\
\text { Distressed Firms }\end{array}$ \\
\hline ROE & $15.75 \%$ & $-25.45 \%$ \\
ROA & $10.81 \%$ & $0.89 \%$ \\
ROD & $4.60 \%$ & $6.98 \%$ \\
Current ratio (CR) & 1.55 & 1.08 \\
Quick ratio (QR) & 0.65 & 0.62 \\
Debt equity ratio (DER) & 2.09 & 28.35 \\
AR_DAYS & 92.45 & 295.36 \\
AP_DAYS & 54.12 & 338.90 \\
INV_DAYS & 72.33 & 220.46 \\
NWC_DAYS & 110.66 & 176.92 \\
\hline
\end{tabular}

The analysis of the data (Table 6) shows the duration of the financial cycle of distressed firms, which have a considerable achievement of capital both in the customer payments cycle $\left(A R \_D A Y S=295.36\right)$ and in the warehouse cycle (INV_DAYS = 220.46). However, such a high duration of the company's financial cycle raises the possibility that there are overlaps in the values of the distressed firms' balance sheets, given that there is a rotation in the corporate active cycle (AR_DAYS + INV_DAYS) of 515.82 days. This duration does not seem to be compatible with the normal cycle of production and sale of tomato firms, which seems to highlight difficulties in financial management (deriving from difficulties in receipts or overvaluation of receivables or inventories) that raise the question of incorrect accounting records in the company balance sheet. As a consequence of this, the commercial liabilities of distressed firms (AP_DAYS) have a payment extension of 338.90; this extension appears to be anomalous and contrary to normal payment practices, which generally align within 90 days of the delivery of the goods or of the provision of the services. Even this anomalous expansion of the payment cycle of trade receivables, highlighted by the anomalous duration of AP_DAYS, is a symptom of the difficulty of the financial crises of distressed firms. The periods of the financial cycle of the not-distressed firms (AR_DAYS $=92.45$, AP_DAYS $=54.12$, INV_DAYS $=72.33$ ) appear, instead, to be standard and in line with the commercial practice of the sector.

Table 6 shows that distressed firms were characterized by lower operating profitability (ROA) than the cost of debt (ROD) and by negative return on risk capital (ROE). The results of the analysis show that the distressed firms were characterized by the absence of established brands (only 1 in 5 firms sold their own brand products) and by less research to reduce the seasonality of production ( 3 out of 5 firms did not produce goods during the winter period, but only conducted maintenance). Furthermore, the fact that distressed firms belonged to small family groups may have led to a reduction in contributions from venture capital, with consequent limitation to the access to capital. This limitation may have led to reductions in the level of plant upgrades, in commercial promotion, in investment in research and development and a worsening in the conditions of access to credit. Moreover, the absence of minority shareholders in these firms may reduce control over firm decisions and reduce the efficient use of firm capital. However, this study did not have precise information on these issues, which could be developed in future research on a larger sample of firms.

\subsection{Comparison between BSS, IS and FR Values in the Distressed and Not-Distressed Firms Sample}

In the last part of the analysis, we tested whether there were statistically significant differences between the patrimonial values of BSS, between the economic margins of IS and between FR in the distressed and not-distressed firms. As shown before, the Kolmogorov-Smirnov D statistic on normality of distribution shows that all values (BSS, IS and FR values) do not follow a normal distribution; it was necessary to apply a nonparametric approach, such as the Mann-Whitney U-statistic, for independent samples. Our analysis (Table 7) considered a total of 20 comparisons, with 5 comparisons between BSS values, 5 comparisons between IS values and 10 comparisons between FR values. The BSS comparisons highlight that it is possible to reject the null hypothesis 
of equality between means by applying a two-sided test with a $1 \%$ significance in 3 out of 5 cases. The capital structure of not-distressed and distressed firms differs particularly for the different level of ineptness and for the equity capital level (respectively, comparisons 4 and 5). The IS comparisons show that it is possible to reject the null hypothesis of equality between means by applying a two-sided test with a $1 \%$ significance in 3 out of 5 cases. The IS margins of not-distressed and distressed firms differ particularly for the different level of EBIT margins and for the profit margins ( $\Pi^{\mathrm{bT}}$ and $\Pi$ ). The FR comparisons highlight that it is possible to reject the null hypothesis of equality between means by applying a two-sided test with a $1 \%$ significance in 7 out of 10 cases. The FR of not-distressed and distressed firms differs particularly for the difference level of FR with income focus (ROE and ROA) and for the difference of FR in the NWC duration (AR_DAYS, AP_DAYS, INV_DAYS).

Table 7. A comparison of economic and financial data applying a nonparametric approach for independent samples (Mann-Whitney U-statistic).

\begin{tabular}{|c|c|c|c|c|}
\hline $\begin{array}{c}\text { Comparisons (DF Is Distressed Firms and } \\
\text { NDF Is Not-Distressed Firms) }\end{array}$ & Type & $\begin{array}{l}\text { Mann-Whitney } \\
\text { U-Statistic }\end{array}$ & $\begin{array}{l}\text { Observations } \\
\quad(24+10)\end{array}$ & $\begin{array}{c}\text { Statistical } \\
\text { Significance (2-Tailed) }\end{array}$ \\
\hline Comp. 1: $\mathrm{BFA}_{\mathrm{DF}}-\mathrm{BFA}_{\mathrm{NDF}}$ & $\mathrm{BSS} \%$ of TS & $3.121^{\mathrm{a}}$ & 34 & $0.000 * *$ \\
\hline Comp. 2: $\mathrm{CwC} \mathrm{c}^{\mathrm{ar}<12 \mathrm{~m}} \mathrm{DF}^{-\mathrm{C} w \mathrm{C}^{\mathrm{ar}}<12 \mathrm{~m}} \mathrm{NDF}$ & $\mathrm{BSS} \%$ of TS & $-1.725^{b}$ & 34 & $0.031 *$ \\
\hline Comp. 3: Couple $1 \mathrm{CW}^{\mathrm{ci}}{ }_{\mathrm{DF}}-\mathrm{CW}^{\mathrm{ci}} \mathrm{NDF}$ & BSS $\%$ of TS & $-1.492^{b}$ & 34 & 0.134 \\
\hline Comp. 4: $\mathrm{D}^{\mathrm{T}}{ }_{\mathrm{DF}}-\mathrm{D}^{\mathrm{T}} \mathrm{NDF}$ & $\mathrm{BSS} \%$ of TS & $-3.762^{b}$ & 34 & $0.000 * *$ \\
\hline Comp. 5: $E_{D F}-E_{N D F}$ & $\mathrm{BSS} \%$ of TS & $8.141^{\mathrm{a}}$ & 34 & $0.000 * *$ \\
\hline Comp. 6: EBITDA ${ }_{\mathrm{DF}}-\mathrm{EBITDA}_{\mathrm{NDF}}$ & IS\% of $S$ & $1.207^{\mathrm{a}}$ & 34 & 0.211 \\
\hline Comp. 7: EBIT $_{\mathrm{DF}}-\mathrm{EBIT}_{\mathrm{NDF}}$ & IS $\%$ of $S$ & $3.525^{\mathrm{a}}$ & 34 & $0.000^{* *}$ \\
\hline Comp. 8: $\mathrm{SF}_{\mathrm{DF}}-\mathrm{SF}_{\mathrm{NDF}}$ & IS\% of S & $-0.952^{b}$ & 34 & 0.340 \\
\hline Comp. 9: $\Pi^{\mathrm{bT}}{ }_{\mathrm{DF}}-\Pi^{\mathrm{bT}} \mathrm{NDF}$ & IS $\%$ of $S$ & $5.140^{\mathrm{a}}$ & 34 & $0.000 * *$ \\
\hline Comp. 10: $\Pi_{\mathrm{DF}}-\Pi_{\mathrm{NDF}}$ & IS $\%$ of $S$ & $6.190^{\mathrm{a}}$ & 34 & $0.000 * *$ \\
\hline Comp. 11: $\mathrm{ROE}_{\mathrm{DF}}-\mathrm{ROE}_{\mathrm{NDF}}$ & FR values & $3.428^{\mathrm{a}}$ & 34 & $0.000 * *$ \\
\hline Comp. 12: $\mathrm{ROA}_{\mathrm{DF}}-\mathrm{ROA}_{\mathrm{NDF}}$ & FR values & $2.995^{\mathrm{a}}$ & 34 & $0.000 * *$ \\
\hline Comp. 13: ROD $_{\mathrm{DF}}-\mathrm{ROD}_{\mathrm{NDF}}$ & FR values & $1.898^{\mathrm{a}}$ & 34 & $0.041 *$ \\
\hline Comp. 14: $\mathrm{CR}_{\mathrm{DF}}-\mathrm{CR}_{\mathrm{NDF}}$ & FR values & $1.019^{\mathrm{a}}$ & 34 & 0.275 \\
\hline Comp. 15: $\mathrm{QR}_{\mathrm{DF}}-\mathrm{QR}_{\mathrm{NDF}}$ & FR values & $0.395^{a}$ & 34 & 0.420 \\
\hline Comp. 16: DER $_{\mathrm{DF}}-\mathrm{DER}_{\mathrm{NDF}}$ & FR values & $-10.290^{b}$ & 34 & $0.000 * *$ \\
\hline Comp. 17: AR_DAYS ${ }_{D F}-A R \_D A Y S_{N D F}$ & FR values & $-6.341^{b}$ & 34 & $0.000 * *$ \\
\hline Comp. 18: AP_DAYS ${ }_{D F}-A P \_D A Y S_{N D F}$ & FR values & $-8.380^{b}$ & 34 & $0.000 * *$ \\
\hline Comp. 19: INV_DAYS ${ }_{D F}-I N \bar{N}_{-}$DAYS ${ }_{\mathrm{NDF}}$ & FR values & $-7.221^{b}$ & 34 & $0.000 * *$ \\
\hline Comp. 20: WC_DAYS ${ }_{D F}-N W C \_D A Y S_{N D F}$ & FR values & $-3.097^{b}$ & 34 & $0.000 * *$ \\
\hline
\end{tabular}

The statistical analysis conducted with the Mann-Whitney U-statistic confirms the outcome of the descriptive statistics analysis. It is therefore confirmed that the distressed firms in the tomato processing sector are highly indebted and characterized by low profit margins, when compared with not-distressed firms. In particular, distressed firms showed a statistically lower return on capital (ROA) than not-distressed firms, and lower than the cost of debt (ROD). Moreover, analysis of the failed firms highlighted non-statistically different $C R$ and $Q R$ values relating, in particular, to receivables and to the value of the company stock, (which may be affected by the company before the failure of the firms), with an ensuing underestimation of the probability of default, and the consequent risk for any third parties. The impact on the occurrence of the risk factors is therefore assumed. A line of research could be developed to test the presence of manipulations on accounting data in firms that failed, specifically for the tomato sector, in order to highlight elements useful for the ex ante individuation (prior to the business disruption) of possible accounting frauds. On this subject, although not pertaining to the tomato sector, interesting work has been carried out by many researchers [58-60].

\section{Conclusions}

Since 2015, the tomato sector has returned to benefiting from coupled support. It emerged that the competitiveness of the sector is increasingly linked to the support of the Common Agricultural Policy (CAP) and is increasingly dependent on technical and organizational innovation in the supply chain [61]. In recent years, in the Italian tomato processing sector, there has been a gradual 
concentration of production, with an increase in the average size of firms and various business crises, especially for smaller firms. This change in the structure of firms, although analyzed from the perspectives of consumer market trends and the supply of raw materials, has not yet been analyzed from the point of view of the analysis of financial sustainability and management efficiency.

The research highlights that processing firms in the tomato sector in northern Italy are often characterized by a significant absorption of capital to finance investments in fixed assets and in the cycle of working capital. This characteristic of the financial cycle might be amplified given that the tomato processing sector has a seasonal pick in summer, during the months of August and September, with a concentration in production and the employment of seasonal workers during the production season. In order to reduce the financial exposure connected with the seasonality of the business cycle, only a few firms have a wide range of production, including canned vegetables and juices. The analysis highlights firms' difficulties with regards to the financial sustainability of the business cycle, as evidenced by the reduction in the number of firms that are active in the sector, which is also a result of bankruptcy proceedings that have affected the firms in the last decade. The research, carried out on tomato processing firms operating in northern Italy, dividing firms into still-active firms and failed firms, with the aim of analyzing the differences between the two groups of firms, produced the following major results:

1. The distressed firms in the sector are, on average, smaller, both for invested capital and for turnover.

2. The distressed firms in the sector have higher recourse to debt capital on average and generate lower profit margins than not-distressed firms.

3. The failed firms have significantly different FR compared to non-bankrupt firms, and this allows having ex ante indications of the risk level of the company, by analyzing the data of the FR.

4. The FR related to the business liquidity cycle highlight the high duration of the business cycle of the firm and this raises the question of the manipulation of accounting data (particularly in inventories and commercial credit data), which could be usefully explored via further research in the sector.

The company data suggest that larger firms, characterized by an adequate financial structure in terms of equity, have been able to withstand the tomato market crisis in recent years. The results of the research showed that smaller firms are characterized by worse performance; in fact, the distressed firms are smaller and have caused damage to the economic system, including job losses and losses of money to suppliers, banks and the State. This study highlights that smaller firms have experienced higher levels of disruption, and therefore, incentive policies should be encouraged for business integration. Incentives to firms for the financing of research and development costs were introduced by Article 3 of Decree Law No. 145/2013, subsequently amended by Law No. 190/2015 and Law No. 232/2016, which grants a tax credit to all firms that make investments in research and development until 31 December 2020, thereby supporting the process of improving the efficiency of firms and increasing corporate investments in intellectual capital. Therefore, this study highlights the usefulness of public aggregation policies between firms, encouraging the creation of corporate networks and mergers and vertical and horizontal integration. In this sense, the possibility of carrying out mergers and business transfer operations without payment of taxes should be considered positively; these tax relief operations favor the aggregation of firms which, as this study shows, can guarantee the continuity of firms of the sector. In the case of specific sectors, especially when characterized by a reduced number of firms, it is not possible to apply models that require a high number of observations, due to both the size of the firms and the extent of the observation period. Furthermore, complex models have considerable difficulties of application, as the results of these are often difficult for manager and operators to understand, and who need simplified indicators that are immediately applicable in firm management. In order to give a schematic and easily understandable indication to sector operators, and to limit the distorting effect of 
a small number of observations, this research focused on the comparative analysis of data between distressed and not-distressed firms, without using an insolvency forecasting model.

The research has some limitations. Firstly, the sample analyzed is related to a small number of firms (17) on a time series of 10 years. It could be useful to extend the analysis to a larger sample, including firms operating in the southern regions of Italy. The analysis could be repeated over the next few years, in order to monitor the process of progressive concentration that has characterized the sector in the last years through several M\&A operations. The results show, however, that even a sector with few firms is very differentiated, at least ex post, through financial ratios, which are the management parameters that characterize the distressed firms compared to the not-distressed firms. These results are immediately available to managers and policy makers that operate in the tomato sector.

Acknowledgments: The authors would like to thank analisiaziendale.it for IT assistance.

Author Contributions: The study is a result of the full collaboration of all the authors. However, Mattia Iotti wrote the sections titled "Methods", "Results and Discussion: Overview of the firms' characteristics in tomato sector", "Results and Discussion: Financial Ratio Analysis", "Conclusions" and Giuseppe Bonazzi wrote the sections titled "Introduction", "Results and Discussion: Data Collection and Research Plan", "Results and Discussion: Annual Account Data Analysis", "Results and Discussion: Comparison between BSS, IS and FR valued in distressed and not-distressed firms sample".

Conflicts of Interest: The authors declare no conflict of interest.

\section{References}

1. ISMEA. Available online: http://www.ismea.it/flex/cm/pages/ServeBLOB.php/L/IT/IDPagina/10110 (accessed on 28 February 2018).

2. Branca, G. I riflessi della riforma dell'OCM ortofrutta sulla filiera del pomodoro da industria in Italia. Agriregionieuropa 2008, 4, 41-45.

3. Lombardi, P.; Verneau, F. Il settore del pomodoro trasformato: Tendenze di mercato, struttura e quadro istituzionale. Econ. Agro-Aliment. 2010, 12, 105-124.

4. Frascarelli, A. La politica dei mercati agricoli dell'Ue per il periodo 2014-2020: Un'analisi degli strumenti. Agriregionieuropa 2016, 12, 9-14.

5. Bonazzi, G. Iotti, Comparative applications of income and financial analysis for tomato processing firms in Italy. Agroalimentaria 2015, 21, 113-131.

6. Marques, R.; Berg, S. Risks, contracts and private sector participation in infrastructure. J. Constr. Eng. Manag. 2011, 137, 925-933. [CrossRef]

7. Iotti, M.; Bonazzi, G. Assessment of Biogas Plant Firms by Application of Annual Accounts and Financial Data Analysis Approach. Energies 2016, 9, 713. [CrossRef]

8. Dechow, P.M. Accounting Earnings and Cash Flow as Measures of Firm Performance, the Role of Accounting Accruals. J. Account. Econ. 1994, 18, 3-42. [CrossRef]

9. Dechow, P.M.; Dichev, L. The Quality of Accruals and Earnings, the Role of Accruals Estimation Errors. Account. Rev. 2002, 87, 35-59. [CrossRef]

10. Baños-Caballero, S.; García-Teruel, P.J.; Martínez-Solano, P. Working capital management, corporate performance, and financial constraints. J. Bus. Res. 2014, 673, 332-338. [CrossRef]

11. Padachi, K. Trends in Working Capital Management and its Impact on Firms' Performance, An Analysis of Mauritian Small Manufacturing Firms. Int. Rev. Bus. Res. Pap. 2006, 2, 45-58.

12. Barnes, P. The Analysis and Use of Financial Ratios, A Review Article. J. Bus. Financ. Account. 1982, 144, 449-461. [CrossRef]

13. Lewellen, J.W. Predicting Returns with Financial Ratios. J. Financ. Econ. 2004, 74, 209-235. [CrossRef]

14. Horrigan, J.O. A Short History of Financial Ratio Analysis. Account. Rev. 1968, 43, 284-294.

15. Stern, J.M.; Stewart, G.B.; Chew, D.H., Jr. The EVA ${ }^{\circledR}$ Financial System. J. Appl. Corp. Financ. 1995, 8, 32-46. [CrossRef]

16. Forker, J.; Powell, R. Comparison of error rates for EVA, residual income, GAAP-earnings \& other metric using a long-window Valuation approach. Eur. Account. Rev. 2008, 17, 471-502. 
17. Fisher, R.A. The Use of Multiple Measurements in Taxonomic Problems. Ann. Eugen. 1936, 7, $179-188$. [CrossRef]

18. Beaver, W.H. Financial Ratios as Predictors of Failure. J. Account. Res. 1966, 4, 71-111. [CrossRef]

19. Altman, E.I. Financial Ratios, Discriminant Analysis and Prediction of Corporate Bankruptcy. J. Financ. 1968, 234, 589-609. [CrossRef]

20. Altman, E.I. An emerging market credit scoring system for corporate bonds. Emerg. Mark. Rev. 2005, 6, 311-323. [CrossRef]

21. Johnson, R.B.; Haegn, A.R. Agricultural Loan Evaluation with Discriminant Analysis. J. Agric. Appl. Econ. 1973, 5, 57-62. [CrossRef]

22. Hardy, W.E.; Weed, J.B. Objective Evaluation for Agricultural Lending. J. Agric. Appl. Econ. 1980, 12, $159-164$. [CrossRef]

23. Dimitras, A.I.; Zanakis, S.H.; Zopounidis, C. A survey of business failure with an emphasis on prediction methods and industrial application. Eur. J. Oper. Res. 1996, 90, 487-513. [CrossRef]

24. Lufburrow, J.; Barry, P.J.; Dixon, B.L. Credit Scoring for Farm Loan Pricing. Agric. Financ. Rev. 1984, 44, 8-14.

25. Miller, L.H.; LaDue, E.L. Credit Assessment Models for Farm Borrowers: A Logit Analysis. Agric. Financ. Rev. $1989,49,22-36$.

26. Lyubov, Z;; Pederson, G. Predictors of farm performance and repayment ability as factors for use in risk-rating models. Agric. Financ. Rev. 2003, 63, 41-54.

27. Hofner, R.; Brewer, B.; Escalante, C. Effects of business maturity, experience, and size on farms economic vitality: A credit migration analysis of Farm Service Agency borrowers. Agric. Financ. Rev. 2017, 77, 153-163.

28. Capitanio, F.; Sgroi, F.; Adinolfi, F. Misura delle performance finanziarie e patrimoniali delle aziende agricole: Proposta operativa per un nuovo modello di rating per le aziende agricole. Riv. Econ. Agrar. 2012, 67, 27-44.

29. Gunther, J.W.; Moore, R.R. Early warning models in real time. J. Bank. Financ. 2003, 27, 1979-2001. [CrossRef]

30. Charalambous, C.; Charitou, A.; Kaourou, F. Comparative Analysis of Artificial Neural Network Models: Application in Bankruptcy Prediction. Ann. Oper Res. 2000, 99, 403-425. [CrossRef]

31. Park, C.S.; Han, I. A case-based reasoning with the feature weights derived by analytic hierarchy process for bankruptcy prediction. Expert Syst. Appl. 2002, 23, 255-264. [CrossRef]

32. Shin, K.S.; Lee, T.S.; Kim, H.J. An application of support vector machines in bankruptcy prediction model. Expert Syst. Appl. 2005, 28, 127-135. [CrossRef]

33. Kumar, P.R.; Ravi, V. Bankruptcy prediction in banks and firms via statistical and intelligent techniques: A review. Eur. J. Oper. Res. 2007, 180,1-28. [CrossRef]

34. Chaudhuria, A.; De, K. Fuzzy support vector machine for bankruptcy prediction. Appl. Soft Comput. 2011, 11, 2472-2486. [CrossRef]

35. Lee, M.C.; To, C. Comparison of support vector machine and back propagation neural network in evaluating the enterprise financial distress. Int. J. Artif. Intell. Appl. 2010, 31-43. [CrossRef]

36. Sun, J.; He, K.Y.; Li, H. SFFS-PC-NN optimized by genetic algorithm for dynamic prediction of financial distress with longitudinal data streams. Knowl. Based Syst. 2011, 24, 1013-1023. [CrossRef]

37. Cao, Y.; Wan, G.Y.; Wang, F.Q. Predicting financial distress of Chinese listed companies using rough set theory and support vector machine. Asia Pac. J. Oper. Res. 2011, 28, 95-109. [CrossRef]

38. Iofrida, N.; De Luca, A.I.; Strano, A.; Gulisano, G. Can social research paradigms justify the diversity of approaches to social life cycle assessment? Int. J. Life Cycle Assess. 2018, 23, 464-480. [CrossRef]

39. De Luca, A.I.; Iofrida, N.; Leskinen, P.; Stillitano, T.; Falcone, G.; Strano, A.; Gulisano, G. Life cycle tools combined with multi-criteria and participatory methods for agricultural sustainability: Insights from a systematic and critical review. Sci. Total Environ. 2017, 595, 352-370. [CrossRef] [PubMed]

40. Testa, R.; Trapani, A.D.; Sgroi, F.; Tudisca, S. Economic Sustainability of Italia Greenhouse Cherry Tomato. Sustainability 2014, 6, 7967-7981. [CrossRef]

41. Bonazzi, G.; Iotti, M. Evaluation of biogas plants by the application of an internal rate of return and debt service coverage approach. Am. J. Environ. Sci. 2014, 11, 35-45. [CrossRef]

42. Cupo, P.; Di Domenico, M. I fattori che influiscono sul merito creditizio delle aziende agricole: Un'applicazione in Campania. Riv. Econ. Agrar. 2012, 67, 45-67.

43. ISTAT. Available online: http://agri.istat.it/sag_is_pdwout/jsp/dawinci.jsp?q=plCPO0000010000012000\&

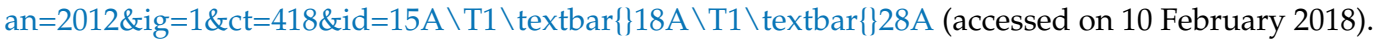

44. ISTAT. Available online: http://agri.istat.it/sag_is_pdwout/jsp/dwExcel.jsp (accessed on 10 February 2018). 
45. OIPOMODORONORDITALIA. Available online: http:/ / www.oipomodoronorditalia.it/?page_id=1269 (accessed on 11 February 2018).

46. LIFEPREFER. Available online: http://www.lifeprefer.it/it-it/Progetto/Prodotti/Pomodoro (accessed on 11 February 2018).

47. Berryman, J. Small Business Failure and Bankruptcy, a Survey of the Literature. Eur. Small Bus. J. 1983, 1, 47-59. [CrossRef]

48. Peel, M.J.; Wilson, N. Working Capital and Financial Management Practices in the Small Firm Sector. Int. Small Bus. J. 1996, 14, 52-68. [CrossRef]

49. Glancey, K. Determinants of Growth and Profitability in Small Entrepreneurial Firms. Int. J. Enterp. Behav. Res. 1998, 4, 18-27. [CrossRef]

50. Dunn, P.; Cheatham, L. Fundamentals of Small Business Financial Management for Start-up, Survival, Growth, and Changing Economic Circumstances. Manag. Financ. 1999, 19, 1-13. [CrossRef]

51. Boschi, M.; Girardi, A.; Ventura, M. Partial credit guarantees and SMEs financing. J. Financ. Stab. 2014, 15, 182-194. [CrossRef]

52. Dothan, M. Costs of Financial Distress and Interest Coverage Ratios. J. Financ. Res. 2006, 29, 147-162. [CrossRef]

53. Love, I.; Preeve, L.; Sarria-Allende, V. Trade Credit and Bank Credit, Evidence from Recent Financial Crisis. J. Financ. Econ. 2007, 83, 453-469. [CrossRef]

54. Hill, M.D.; Kelly, W.G.; Highfield, M.J. Net Operating Working Capital Behavior, A First Look. Financ. Manag. 2010, 2, 783-805. [CrossRef]

55. Molina, C.; Preeve, L. Trade Receivable Policy of Distressed Firms and its Effects on the Cost of Financial Distress. Financ. Manag. 2009, 38, 663-686. [CrossRef]

56. Rosner, R.L. Earnings Manipulation in Failing Firms. Contemp. Account. Res. 2003, 2, 361-408. [CrossRef]

57. Russel, P.B. The Cash Flow Implication of Managing Working Capital and Capital Investment. J. Bus. Econ. Stud. 2009, 15, 98-108.

58. Beneish, M.D. The Detection of Earnings Manipulation. Financ. Anal. J. 1999, 55, 24-36. [CrossRef]

59. Beneish, M.D.; Billings, M.B.; Hodder, L.D. Internal Control Weaknesses and Information Uncertainty. Account. Rev. 2008, 83, 665-703. [CrossRef]

60. Beneish, M.D.; Lee, C.M.C.; Nichols, D.C. Earnings Manipulation and Expected Returns. Financ. Anal. J. 2013, 69, 22-41. [CrossRef]

61. Canali, G. Il pomodoro da industria nel nord italia: L'innovazione organizzativa per migliorare la competitività. Agriregionieuropa 2012, 8, 35-39. 